
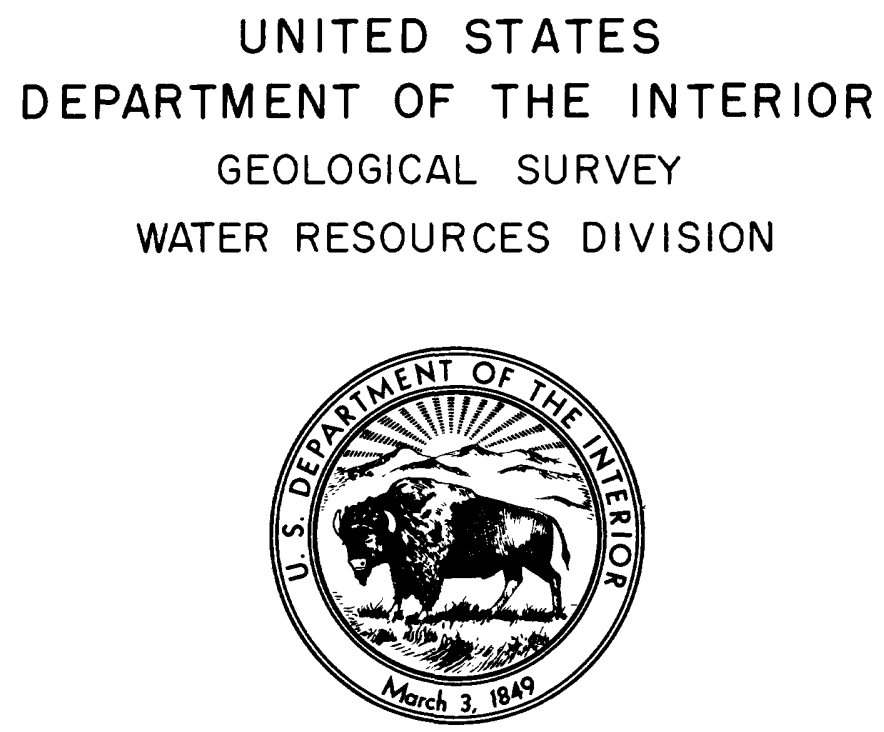

\title{
FLOODS IN THE \\ UPPER DES MOINES RIVER BASIN, IOWA
}

By

Harlan H. Schwob, Hydraulic Engineer

United States Geological Survey

Prepared in cooperation with the

IOWA STATE HIGHWAY COMMISSION

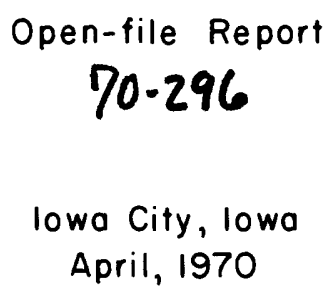

70.296

lowa City, lowa

April, 1970 



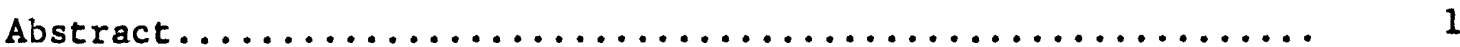

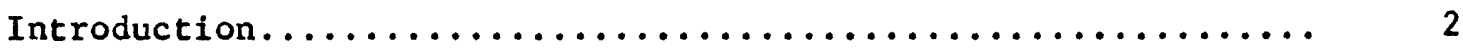

Purpose and scope.......................... 2

Acknowledgments............................ 4

Basin description $\ldots \ldots \ldots \ldots \ldots \ldots \ldots \ldots \ldots \ldots \ldots \ldots \ldots \ldots \ldots \ldots \ldots \ldots \ldots$

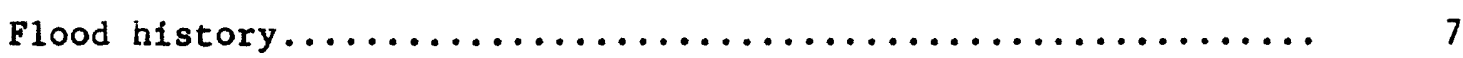

Basic data

Gaging-station records....................... 10

Profile data...................................... 12

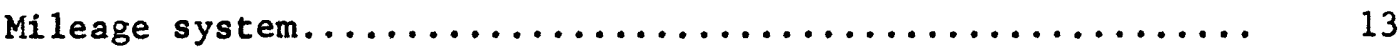

Flood-frequency information.................... 13

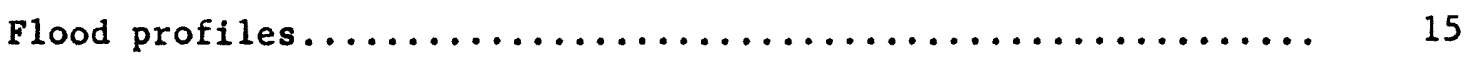

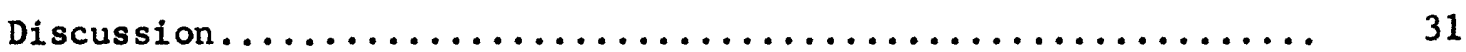

Selected references........................... 32

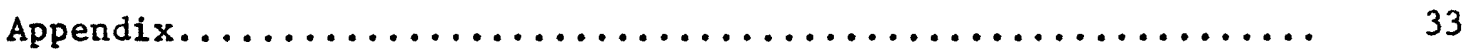

(gaging-station records)

5-4760. West Fork Des Moines River at Jackson, Minn 34

5-4765. West Fork Des Moines River at Estherville, Iowa 35

5-4767.5 West Fork Des Moines River at Humboldt, Iowa 38

5-4780. East Fork Des Moines River near Burt, Iowa 41

5-4790. East Fork Des Moines River at Dakota City, Iowa 43

5-4800. Lizard Creek near Clare, Iowa 45

5-4805. Des Moines River at Fort Dodge, Iowa 46

5-4810. Boone River near Webster City, Iowa 48

5-4815. Des Moines River near Boone, Iowa 49 
ILLUSTRATIONS

Page

Plate 1. Map of upper basin Des Moines River above 3 gaging station near Boone, Iowa

2-5 Main stem Des Moines River profiles mile $16-19$ 269-330

6-9 West Fork Des Moines River profiles mile $20-23$ $330-413$

10-15 East Fork Des Moines River profiles mile 24-29 $330-439$

Figure 1. Flood-frequency curves and 1969 flood peaks for selected gaging stations upper basin Des Moines River

\section{TABLES}

Table 1. Population of cities and towns on or near East and West Forks and main stem Des Moines Rivers, above Boone River

2. Flood peaks at gaging stations in the upper Des Moines River basin for selected years and floods

3. Summary of date and time of peaks of the 1954, 1965, and 1969 floods at gaging stations in upper Des Moines River basin 
FLOODS IN THE UPPER DES MOINES RIVER BASIN, IOWA

by

Harlan H. Schwod

\begin{abstract}
Data on flood stages, discharges, and frequency are used in the design of bridges and other structures and the conduct of various operations on the flood plains of streams. This report provides these data in the form of flood-peak records, gaging-station records, frequency curves, and flood profiles. Information is provided for 253 miles of streams from near Boone on the main stem to the Iowa-Minnesota state line on the East and West Forks of the Des Moines River.

Elood profiles on the main stem include those for the notable flood of 1954, the lesser flood of 1947, and the computed 25- and 50-year floods. On the West Fork, profiles are shown for the outstandIng flood of April 1969; lesser floods in April 1965, July 1964, and September 1964; and the computed 25- and 50-year floods. On the East Fork, profiles are shown for the April 1965 flood from the mouth to Algona and for the April 1969 flood from Algona to Tuttle Lake; for a lesser flood in October 1968; and for the computed 25- and 50-year floods. Low-water profiles are shown for all reaches.

Tabulations of flood stages and discharges at gaging stations contained in this report can be used for volumetric studies. They can also be used to study the time distrioution of stage and discharge above a selected level.
\end{abstract}




\section{INTRODUCTION}

Purpose and Scope

The purpose of this report is to provide flood information for the upper Des Moines River basin. This information can be used for planning, designing, and operating structures and conducting other activities on or across the flood plain and for assessing the severity of floods. The report provides data on (1) basin characteristics, (2) flood history with brief descriptions of the meteorology of storms causing outstanding floods, (3) flood stages and discharges, (4) flood frequency, and (5) profiles of several major floods and of the 25- and 50-year frequency floods. Streams covered by the report are the main stem Des Moines River from below the junction of the Boone River upstream to the junction of the East and West Forks, and the East and West Forks to the Iowa-Minnesota line. Some flood data are given for a gaging station on the West Fork in Minnesota. Two prior reports published by the U.S. Geological Survey contain information on the floods in 1953 and 1954 (see selected references). The discussion section of this report outlines some possible uses and limitations of the data presented. 


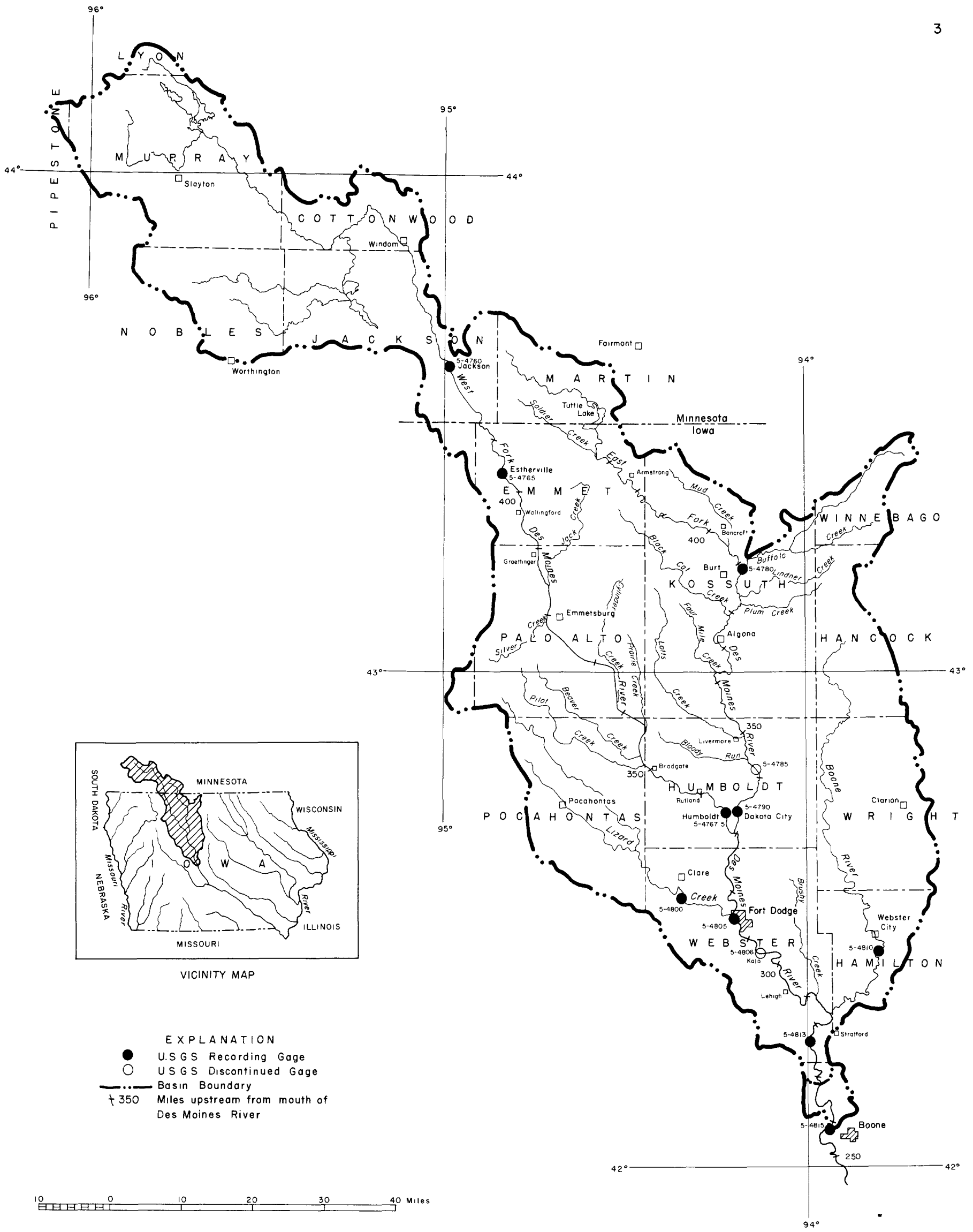




\section{Acknowledgments}

This report is the fourth of a series resulting from a cooperative project with the Iowa State Highway Commission through the Iowa Highway Research Board. Collection of the basic information was generally by the Geological Survey. Profiles of the main stem of the Des Moines River were prepared from flood-elevation data furnished by the Corps of Engineers. Records for stream-gaging stations were obtained as a part of the cooperative program with many city, state and Federal agencies. This cooperation is explained in the U.S. Geological Survey annual publications, "Water Resources Data for Iowa, Part 1, Surface Water Records", after 1960 and in U.S. Geological Survey Water-Supply Papers prior to 1961 .

\section{BASIN DESCRIPTION}

This report covers that part of the Des Moines River basin upstream from mile 269 (15 miles downstream from Boone River) to the Minnesota State line. Plate 1 shows the outline of the basin above this location and also the basin outline above the gaging station near Boone. At this latter point, the area drained is about 38 percent of the total drainage area of the Des Moines River at its mouth. Two major tributaries join at mile 330.4 to form the main stem of the Des Moines River. The West Fork Des Moines River, the larger of the two, has its sources in Pipestone, Lyon, and Murray Counties, Minnesota, and flows easterly and southeasterly to the confluence with the East Fork. The source of the East Fork is in Jackson County, 
Minnesota, from which it flows southeasterly and southerly to join the West Fork. The main stem of the river flows generally southeasterly and southerly to and past the gaging station near Boone, Iowa. The topography of the area is the result of several glaciations modified by subsequent erosion. Above the confluence of the East and West Forks the area is flat with shallow stream channels and extremely wide valleys. The East and West Forks flow through many lakes, particularly in Minnesota. From points a short distance upstream of the confluence of the forks to the lower end of the report area, the valley narrows and the stream channel becomes deeper. The surficial materials covering the area were deposited by the Wisconsin Glacier.

A number of cities and towns lie on or near the flood plains of the Des Moines River and the two Forks. If not directly affected by flooding, they are indirectly affected by the closing of roads, interruption of trade with flooded areas, and other effects which accompany major floods. The 1960 population of 14 cities and towns along the main stem and the two forks is given in table 1 .

The climate of the basin is temperate. Average yearly temperature $(1931-60)$ of the basin in Iowa ranges from about $47^{\circ} \mathrm{F}$ to about $50^{\circ} \mathrm{F}$ from north to south. Normal annual precipitation (1931-60) over the drainage area in Iowa and Minnesota averages about 28.3 inches and ranges from 25 to 31 inches from north to south. 
Table 1. Population of cities and towns on or near East and West Forks and main stem Des Moines Rivers, above Boone River.

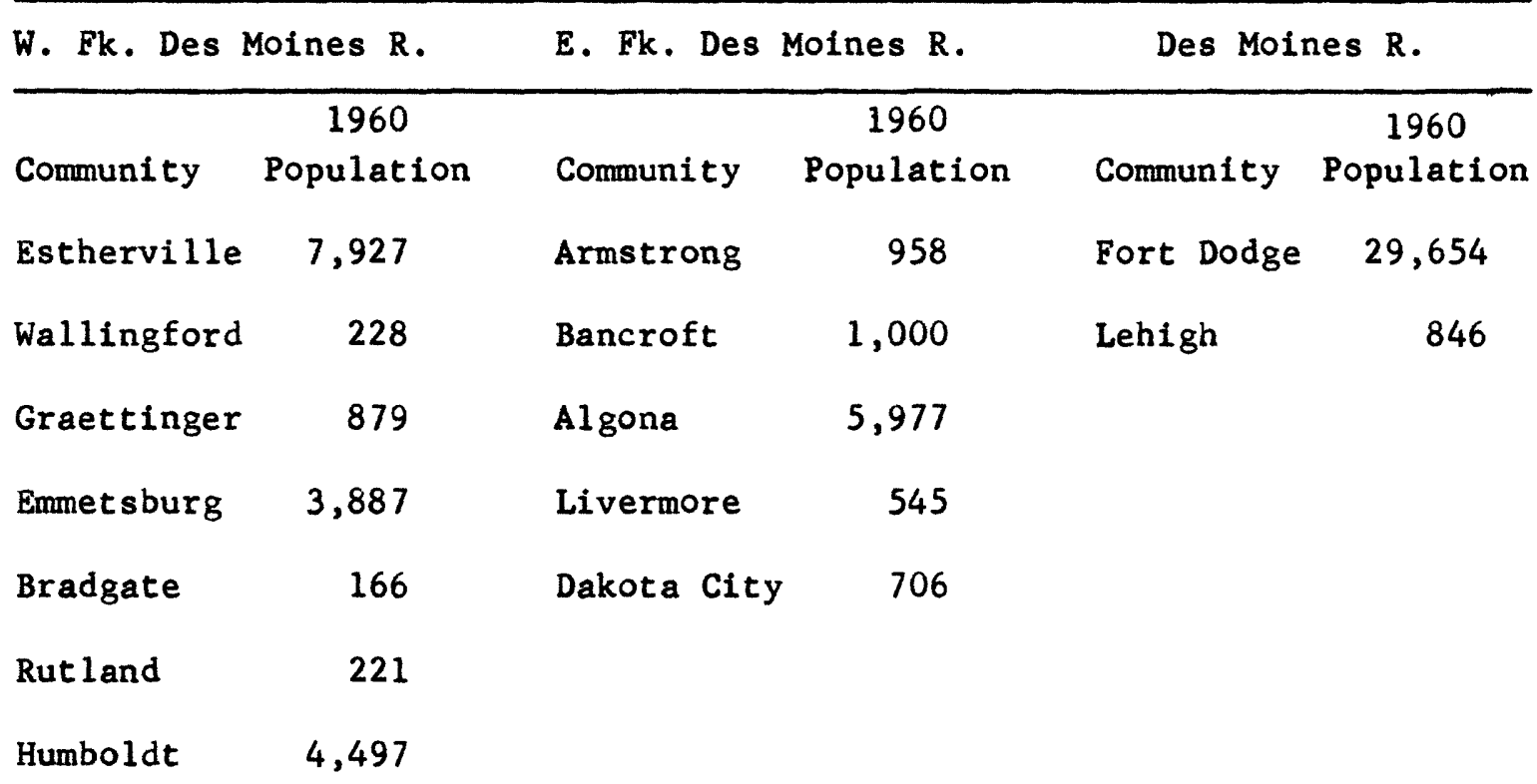


FLOOD HISTORY

Virtually nothing is known of the flood stages and discharges of the Des Moines River basin above the Boone River prior to the establishment of the gaging station near Boone. Precipitation records indicate the possibility of several great floods between 1850 and 1902. At the gaging station near Boone (fig. 1, 5-4815) a flood of 43,600 cfs (cubic feet per second) occurred in May 1903. From that time until June 1947 no flood exceeding a 10-year recurrence interval (37,000 cfs) flood occurred at the station. Floods of relatively great magnitude have occurred on some streams in the drainage basin above the station near Boone in 1918 and subsequent years. These are listed in table 3 .

Major floods in the upper Des Moines River basin generally result from heavy rainfall during the summer months or from snowmelt, often with accompanying rain, in the late winter or early spring. Summer floods occurred in 1918, 1938, 1947, 1953, and 1954. Snowmelt floods occurred in 1951, 1961, 1962, 1965, and 1969. Brief descriptions of the causes of these floods in and after 1938 follow.

During two periods in September 1938 , heavy rainfall caused flooding in the upper Des Moines River basin. In the first period, September 5-8, rain amounting to nearly six inches at places in the basin upstream from Fort Dodge saturated the ground. The second period, September 11-14, had a somewhat lesser amount of rain which fell on wet earth and caused extensive flooding. At East Fork Des Moines River near Hardy (about 8 miles upstream from Dakota City) the peak discharge 
TABLE 2. Flood peaks at gaging stations in the upper Des Moines River vasin for selected years and floods

\begin{tabular}{|c|c|c|c|c|c|c|c|c|c|c|}
\hline \multirow{3}{*}{$\begin{array}{l}\text { Station } \\
\text { number }\end{array}$} & \multirow{3}{*}{ Mile } & \multirow{3}{*}{ Gazing station } & \multirow{3}{*}{$\begin{array}{l}\text { Period of } \\
\text { flood } \\
\text { record }\end{array}$} & \multirow{3}{*}{$\begin{array}{c}\text { Drainage } \\
\text { area } \\
\text { (sq. mi.) }\end{array}$} & \multicolumn{6}{|c|}{ Flood peaks } \\
\hline & & & & & \multicolumn{3}{|c|}{1918} & \multicolumn{3}{|c|}{$14+8$} \\
\hline & & & & & Date & $\begin{array}{l}\text { Gage } \\
\text { height } \\
\text { (ft) }\end{array}$ & $\begin{array}{l}\text { Dis- } \\
\text { narge } \\
\text { (cfs) }\end{array}$ & Date & $\begin{array}{c}\text { Gage } \\
\text { neight } \\
\text { (it) }\end{array}$ & $\begin{array}{l}\text { Dis- } \\
\text { sarge } \\
(\text { (fs) }\end{array}$ \\
\hline $5-4760$ & 426.0 & $\begin{array}{l}\text { west Fork Des Moines R, at } \\
\text { Jackson, Minnesota }\end{array}$ & $\begin{array}{l}\text { 1909-13, } \\
1931-\end{array}$ & 1,220 & $\cdots$ & $\cdots$ & $\cdots$ & $4 / 8-10$ & 10.01 & 2,200 \\
\hline $5-4765$ & 404.2 & $\begin{array}{l}\text { West Fork Des Moines R. at } \\
\text { Estherville }\end{array}$ & $1952-$ & 1,372 & $\cdots$ & $\cdots$ & $\cdots$ & $\cdots$ & $\cdots$ & $\cdots$ \\
\hline $5-4767.5$ & 334.3 & $\begin{array}{l}\text { West Fork Des Moines } R \text {. at } \\
\text { Humboldt }\end{array}$ & $1940-$ & 2,256 & $\cdots$ & $--\cdot$ & $\cdots$ & $\cdots$ & --- & --- \\
\hline $5-4780$ & 389.7 & $\begin{array}{l}\text { East Fork Des Moines } R \text {. near } \\
\text { Burt }\end{array}$ & $1952-$ & 462 & $\cdots$ & $\cdots$ & -. & -. & $\cdots$ & $\cdots$ \\
\hline $5-4790$ & $333 . \varepsilon$ & $\begin{array}{l}\text { East Fork Des Moines R. at } \\
\text { Dakota City }\end{array}$ & $\begin{array}{l}1938 \\
1940\end{array}$ & 1,308 & $\cdots$ & $\cdots$ & $\cdots$ & 9/. & $a_{17.4}$ & $a_{22,000}$ \\
\hline $5-4800$ & $\cdots$ & Lizard Creek near Clare & $1940=$ & 257 & $\cdots$ & $\cdots$ & $\cdots$ & $\cdots$ & $\cdots$ & $\cdots$ \\
\hline$j-4805$ & 314.6 & Des Moines $R$. at Fort Dodge & $\begin{array}{l}\text { 1905-06, } \\
1914-27, \\
1947-\end{array}$ & 4,190 & $6 / 4$ & $b_{10.1}$ & ${ }^{\circ} 11,400$ & $\cdots$ & -.. & $\cdots$ \\
\hline $5-4810$ & $\cdots$ & Boone R. near webster City & $\begin{array}{l}1918 \\
1932, \\
1940-\end{array}$ & 844 & $6 / 10$ & ${ }^{c} 19.1$ & 21,500 & $\cdots$ & $\cdots$ & $\cdots$ \\
\hline $5-4815$ & 258.8 & Des Moines $R$. near Boone & $\begin{array}{l}1903 \\
1905-29 \\
1931\end{array}$ & 5,511 & $6 / 6$ & 20.5 & 31,400 & $9 / 18$ & 16.0 & 24,500 \\
\hline
\end{tabular}

\begin{tabular}{|c|c|c|c|c|c|c|c|c|c|c|c|c|}
\hline \multirow{3}{*}{$\begin{array}{l}\text { Station } \\
\text { number }\end{array}$} & \multicolumn{12}{|c|}{ Flood peaks } \\
\hline & \multicolumn{3}{|c|}{1947} & \multicolumn{3}{|c|}{1951} & \multicolumn{3}{|c|}{1953} & \multicolumn{3}{|c|}{1954} \\
\hline & Date & $\begin{array}{c}\text { Gare } \\
\text { neight } \\
\text { (ft) }\end{array}$ & $\begin{array}{c}\text { Dis- } \\
\text { charge } \\
\text { (cfs) }\end{array}$ & Date & $\begin{array}{c}\text { Gage } \\
\text { height } \\
\text { (ft) }\end{array}$ & $\begin{array}{c}\text { Dis. } \\
\text { charge } \\
(=\mathrm{fs})\end{array}$ & Date & $\begin{array}{c}\text { Gage } \\
\text { neight } \\
(\mathrm{ft})\end{array}$ & $\begin{array}{c}\text { Dis. } \\
\text { charge } \\
\text { (cfs) }\end{array}$ & Date & $\begin{array}{c}\text { Gage } \\
\text { height } \\
\text { (ft) }\end{array}$ & $\begin{array}{c}\text { Dis- } \\
\text { charge } \\
\text { (cfs) }\end{array}$ \\
\hline $5-4760$ & $7 / 4$ & 4.29 & 2,100 & $4 / 10$ & 14.73 & 4,380 & $6 / 8$ & 17.43 & 8,360 & $\begin{array}{l}3 / 25 \\
6 / 16\end{array}$ & $\begin{array}{l}7.95 \\
6.07\end{array}$ & $\begin{array}{r}1,160 \\
602\end{array}$ \\
\hline $5-4765$ & $\cdots$ & $\cdots$ & $\cdots$ & $\cdots$ & $\cdots$ & $\cdots$ & $6 / 8$ & 15.53 & 10,800 & $6 / 21$ & 5.66 & 1,360 \\
\hline $5-4767.5$ & $6 / 23$ & 12.2 & 11,000 & $4 / 5$ & 11.30 & 8,980 & $0 / 13$ & 9.64 & 6,280 & $6 / 22$ & 11.33 & 9,490 \\
\hline $5-4780$ & $\cdots$ & $\cdots$ & $\cdots$ & $\cdots$ & $\cdots$ & $\cdots$ & $6 / 13$ & 10.36 & 1,060 & $6 / 21$ & 12.67 & 3,870 \\
\hline $5-4790$ & $6 / 23$ & $a_{15.4}$ & $a_{11,800}$ & $4 / 9$ & ${ }^{a_{14.95}}$ & ${ }^{a} 10,800$ & $6 / 9$ & $a ; .33$ & ${ }^{a} 1,340$ & $\begin{array}{l}6 / 21 \\
6 / 21\end{array}$ & $\begin{array}{r}a_{16.95} \\
24.02\end{array}$ & $\begin{array}{r}{ }^{{ }_{1}} 18,800 \\
17,400\end{array}$ \\
\hline $5-4800$ & $6 / 23$ & 16.0 & $10,0,0$ & $3 / 28$ & 10.42 & 3,620 & $6 / 28$ & 6.54 & 1,190 & $6 / 20$ & 13.21 & 6,210 \\
\hline$s-4805$ & $6 / 23$ & 19.7 & 34,000 & $4 / 8$ & 12.13 & 22,300 & $6 / 13$ & 7.14 & 8,850 & $6 / 21$ & 19.28 & 35,400 \\
\hline $5-4810$ & $6 / 25$ & 12.75 & 9,340 & $\begin{array}{l}3 / 29 \\
4 / 7\end{array}$ & $\begin{array}{l}13.00 \\
11.00\end{array}$ & $\begin{array}{l}9,800 \\
7,070\end{array}$ & $s / 1$ & 5.72 & 1,760 & $6 / 22$ & 18.55 & 20,300 \\
\hline $5-4815$ & $6 / 24$ & 19.8 & 37,100 & $\begin{array}{l}3 / 30 \\
4 / 9\end{array}$ & $\begin{array}{l}16.82 \\
16.44\end{array}$ & $\begin{array}{l}28,200 \\
27,200\end{array}$ & $6 / 15$ & 6.03 & 9,080 & $6 / 22$ & 25.35 & 57,400 \\
\hline
\end{tabular}

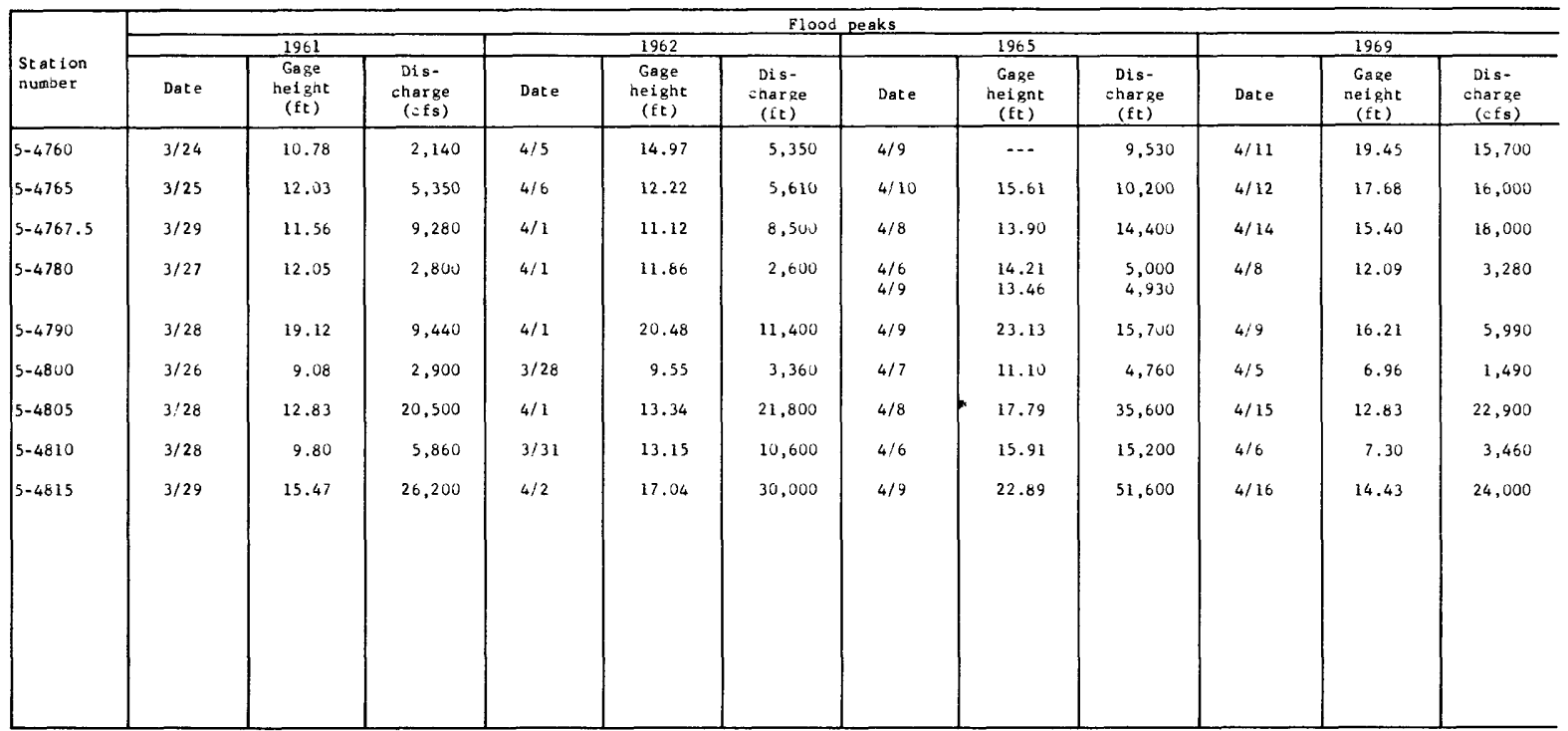


of $22,000 \mathrm{cfs}$ (see table 2) has not been exceeded to date. Other gages in the area were not in operation during 1938.

June 1947 was cool and wet with rainfall in the upper Des Moines River basin on 19 of the 30 days and monthly precipitation totals from 8 to 12.5 inches. As shown in table 2, major floods were extensive in that part of the upper basin in Iowa with the peak flows occurring during the period of June 23-25.

In 1951 the month of March was cold with record snowfall. Late in the month rains and warm weather hastened the snowmelt and caused flooding. Flood discharges were large although not of record proportions in the upper Des Moines River basin.

The floods of June 1953 and June 1954 were caused by exceptionally heavy rainfall. Most of the heavy rainfall in 1953 occurred west of the Des Moines basin and, as shown in table 3, only the West Fork Des Moines River at Estherville had a flood of outstanding size. WaterSupply Paper 1320-A of the U.S. Geological Survey (see references) contains a description of the causes and details of the 1953 floods. In 1954 the center of the heavy June rains was near the eastern boundary of the basin with 8-day totals exceeding 12 inches. All of the basin above Fort Dodge received rainfall in excess of 6 inches. Record peak discharges occurred on the East Fork and on the main stem downstream as far as Des Moines. A detailed report of the flood is published (Yost, 1958).

The snowmelt floods of 1961, 1962, 1965, and 1969. were caused by conditions similar to those that produced the 1951 flood. All 
were notable floods, although, those in 1961 and 1962 were generally smaller than that of 1951. The 1965 floods were about equal to or slightly smaller than the 1954 summer flood (table 2). The 1969 flood produced the peak discharge of record along the West Fork. The flood on the East Fork was less severe so that the combination of flows from the two forks was not sufficient to produce an outstanding flood at Fort Dodge and other downstream places.

An appendix to this report contains tabulations of time, gage height, and discharge for the 1965 and 1969 floods. Similar data for the floods in 1953 and 1954 are contained in Water-Supply Papers 1320-A and 1370-A. These data may be used to plot hydrographs of either gage height or discharge and to compute flood volumes.

The data and time of occurrence of peak discharges in 1954, 1965, and 1969 are summarized in table 3.

\section{BASIC DATA}

\section{Gaging-station Records}

Nine complete-record gaging stations are operated by the U.S. Geological Survey within the basin above the gaging station near Boone (mile 258.8). This latter station will be in the pool of the Saylorville Dam and has been moved to a site at mile 276.7 near Stratford (no. 5-4813, plate 1). Records at the two sites are considered equivalent. Records at the old site are used in this report. Five of the other eight gages are located on rivers having profiles in this report. Data for one of the other stations in Minnesota and two stations in Iowa on tributaries of the main stem are included in the flood records (table 2) and in the descriptive data in the appendix. 


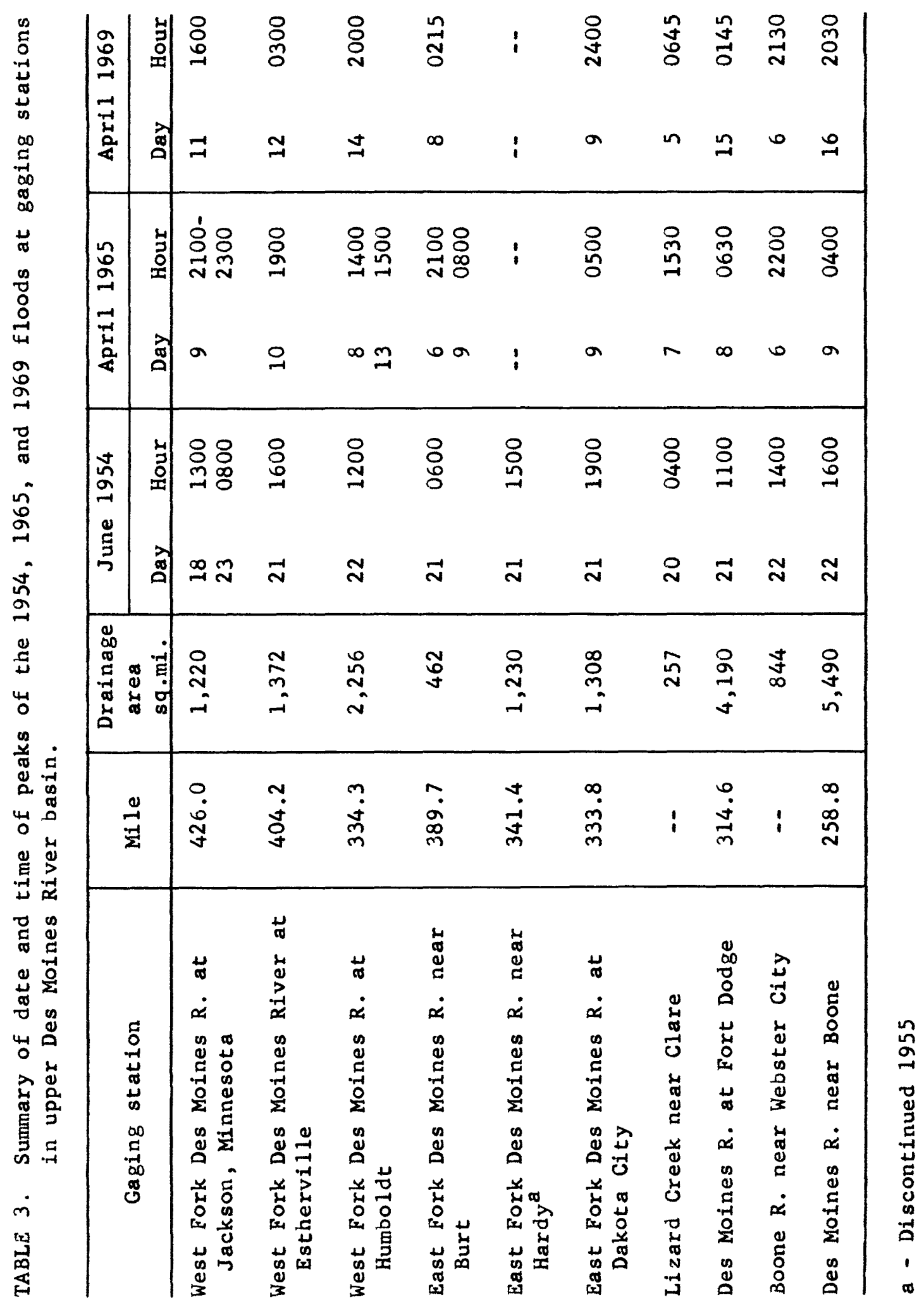


Ice cover prevailed at many places along the streams during the first few days of April 1965 and 1969. The backwater effect caused by ice cover is highly variable particularly during rising stages. During the period of this effect at gaging stations, only daily mean discharges were computed. During open-water periods, the days of flood discharges have been subdivided and the gage height and discharge tabulated with the gaging-station data. These tabulations permit the plotting of detailed hydrographs over the peak period of the floods.

\section{Profile Data}

High-water marks of the individual floods furnish the elevation data for plotting the flood profiles. These marks were obtained as soon as possiole after the peak. Marks were set at bridges to define the peak water-surface elevation upstream and downstream. Additional marks were set between bridges where necessary in order to define water-surface elevations along the stream. High-water marks were tied to mean sea level using the datum of the 1929 general adjustment. Elevations of the 1953 and 1954 floods were ootained from Water-Supply Papers 1320-A and 1370-A.

Data on low-water elevation and discharge were obtained along the streams and are shown on the profile sheets. These data indicate the approximate range in stage and, to some extent, in discharge along the rivers. Discharge at the time of measurement was not the lowest of record. 
Flood-discharge measurements were made at several locations in the basin to supplement data obtained at gaging stations.

Drainage area at selected points along the streams are tabulated on the profiles. The location of the mouths of major tributaries are also shown on the profiles. Drainage area of these tributaries can be computed from the tabulated drainage areas on the profile sheets.

\section{Mi leage System}

River mileages on the basin map and profiles are in miles upstream of the mouth of the Des Moines River. They are based upon the mileage system of the Corps of Engineers modified slightly to account for changes in the stream alignment. Bridges, creeks, and other easily identified points are indicated on the profiles. The mileages between these points can be adjusted proportionately if they do not agree with the users map mileage. An index number, such as $8828-6 \mathrm{SW}$, is shown at bridges and other points to aid in identifying the map location. The number $8828-6 \mathrm{SW}$ indicates a location in Twp. 88 N., R.28 W., the the southwest quarter of section 6 .

\section{Flood-frequency Information}

The computation of the flood discharges tabulated on the profiles (p1s. 2-15) for the 25- and 50-year recurrence interval floods is based upon the report by Schwob (1966). 


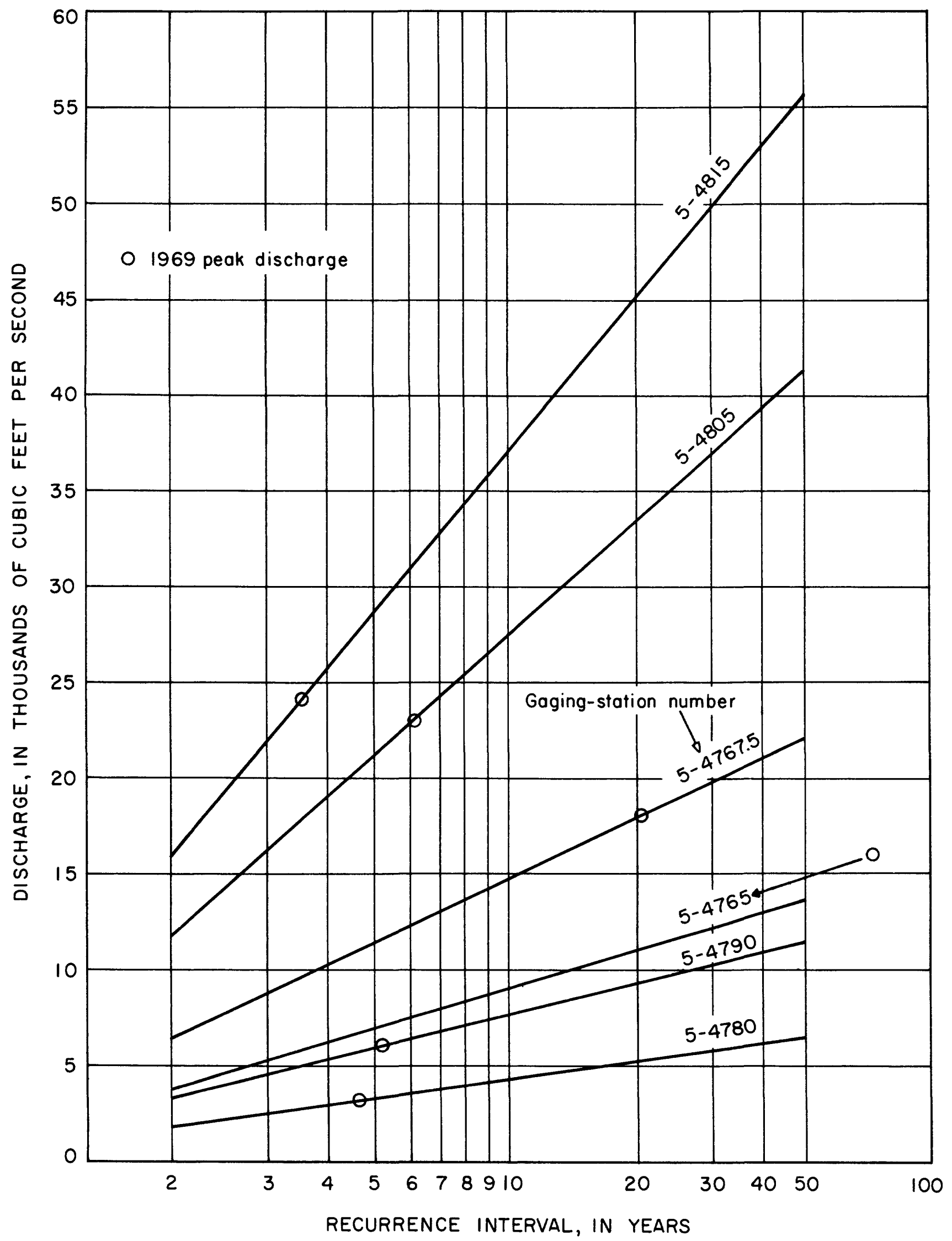

Figure 1. Flood-frequency curves and 1969 flood peaks for selected gaging stations upper Des Moines River basin. 
Flood-frequency curves for six selected gaging stations in the report area are shown in figure 1. These curves show the peak discharge for recurrence intervals from 2 to $50^{\circ}$ years. They can also de used to determine the recurrence interval for any annual peak discharges in the record for each station shown (1969 flood peak is indicated on each curve).

\section{FLOOD PROFILES}

The basic data described were used to prepare flood profiles along the streams. High-water marks defined the known peak elevations for each profile. The gaging-station records and supplemental discharge measurements provided the peak discharges tabulated on the profile sheets (plates 2-15). The computed discharges and elevations for the 25- and 50-year recurrence interval floods have been used to prepare profiles for these two floods.

The profile elevations and the tabulated discharges provide the data for preparation of a partial elevation-discharge relation curve. Such a curve may be prepared for any point on the stream--the only requirement being that the profile elevations and the tabulated discharges are sufficient in number and distribution to adequately define the curve within the range of interest. 
$\simeq$

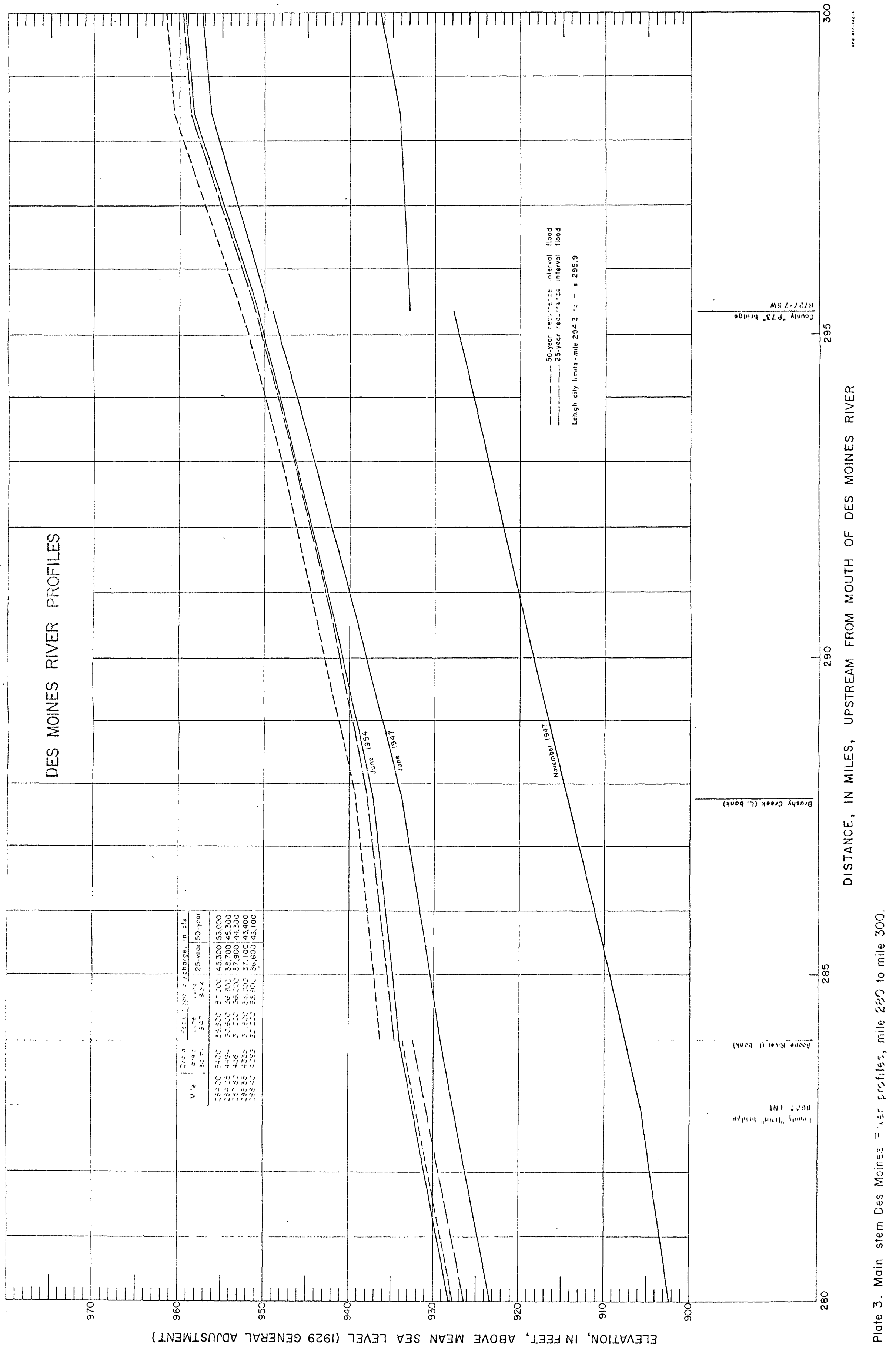




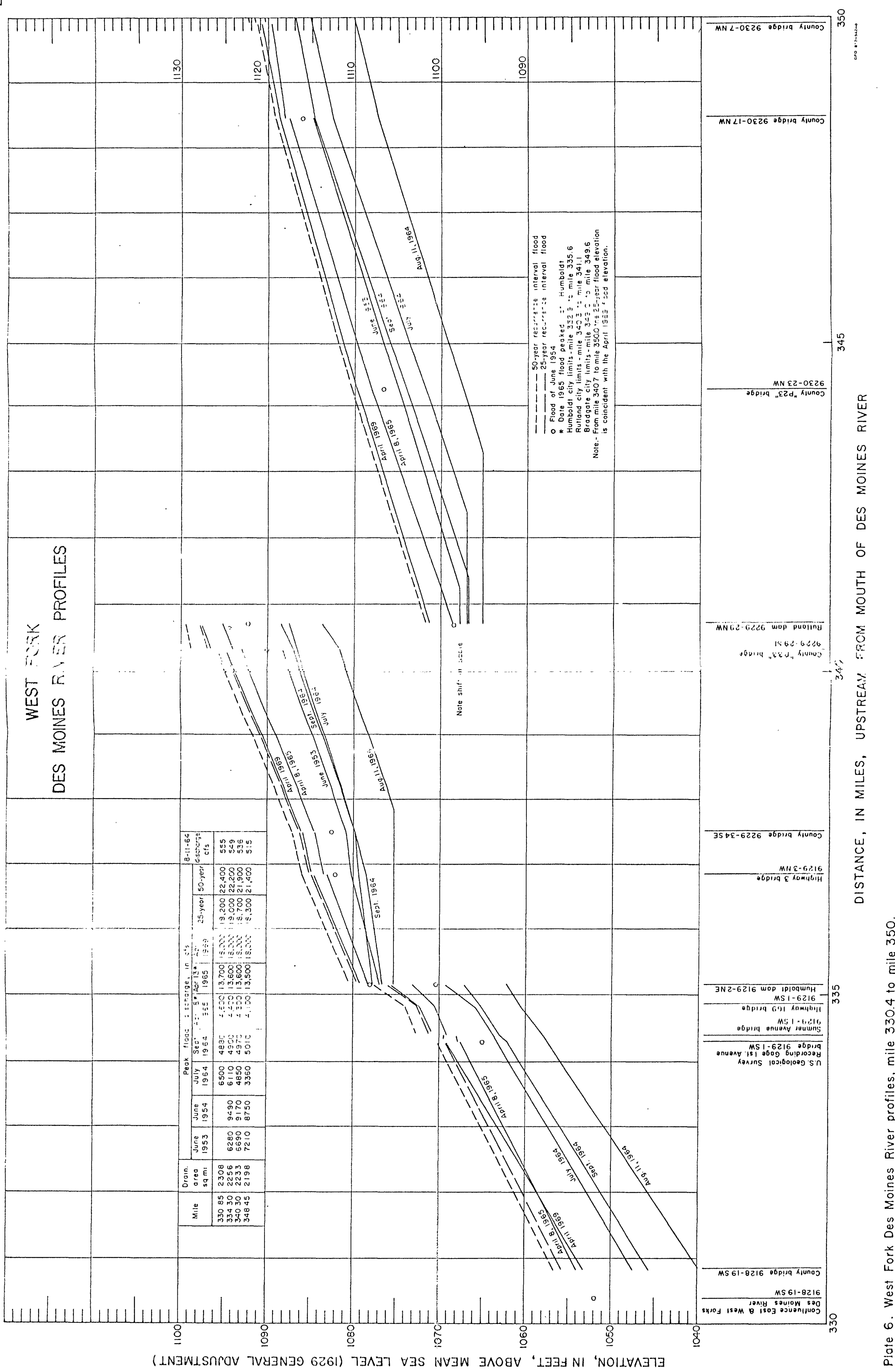




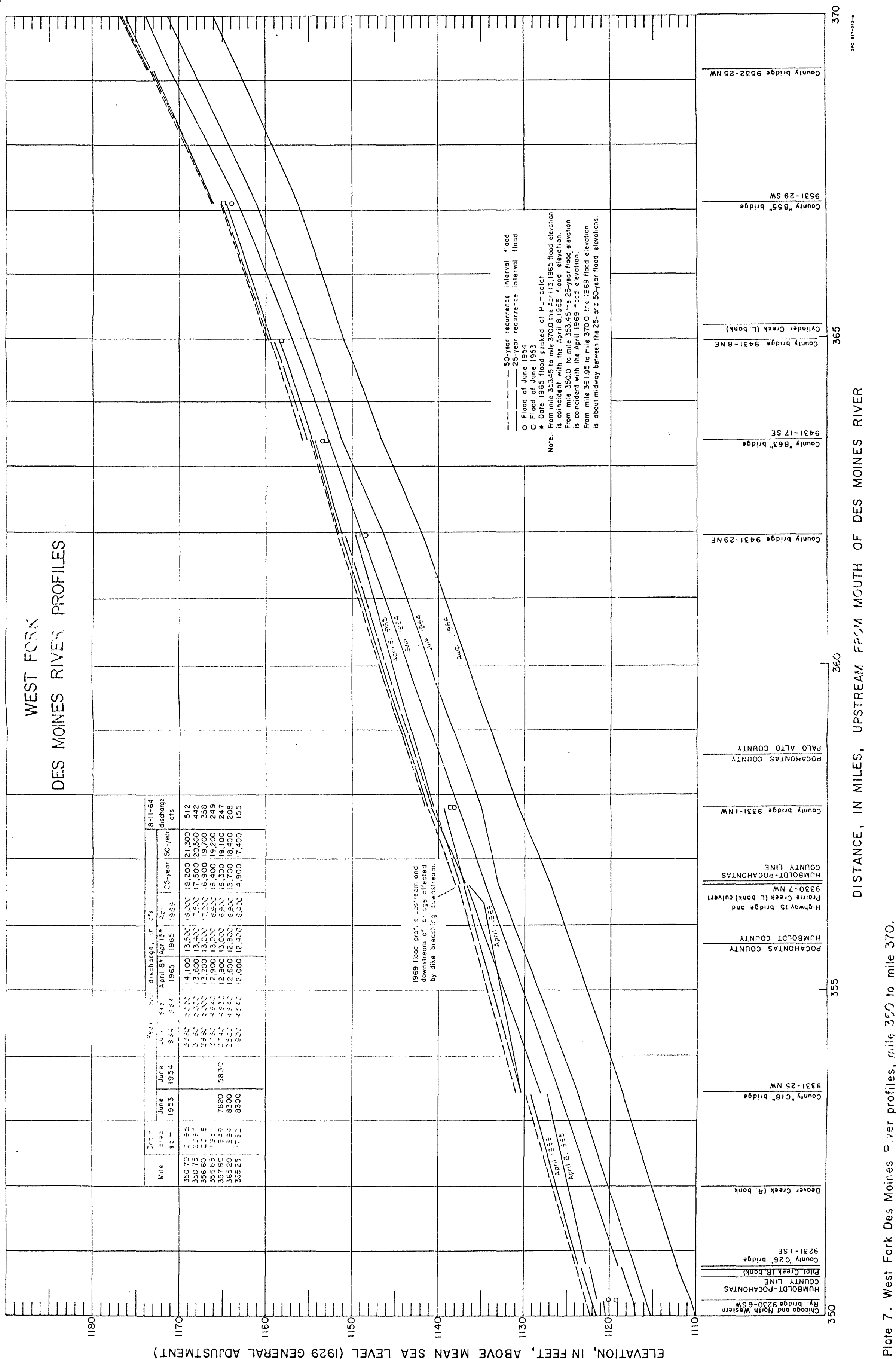




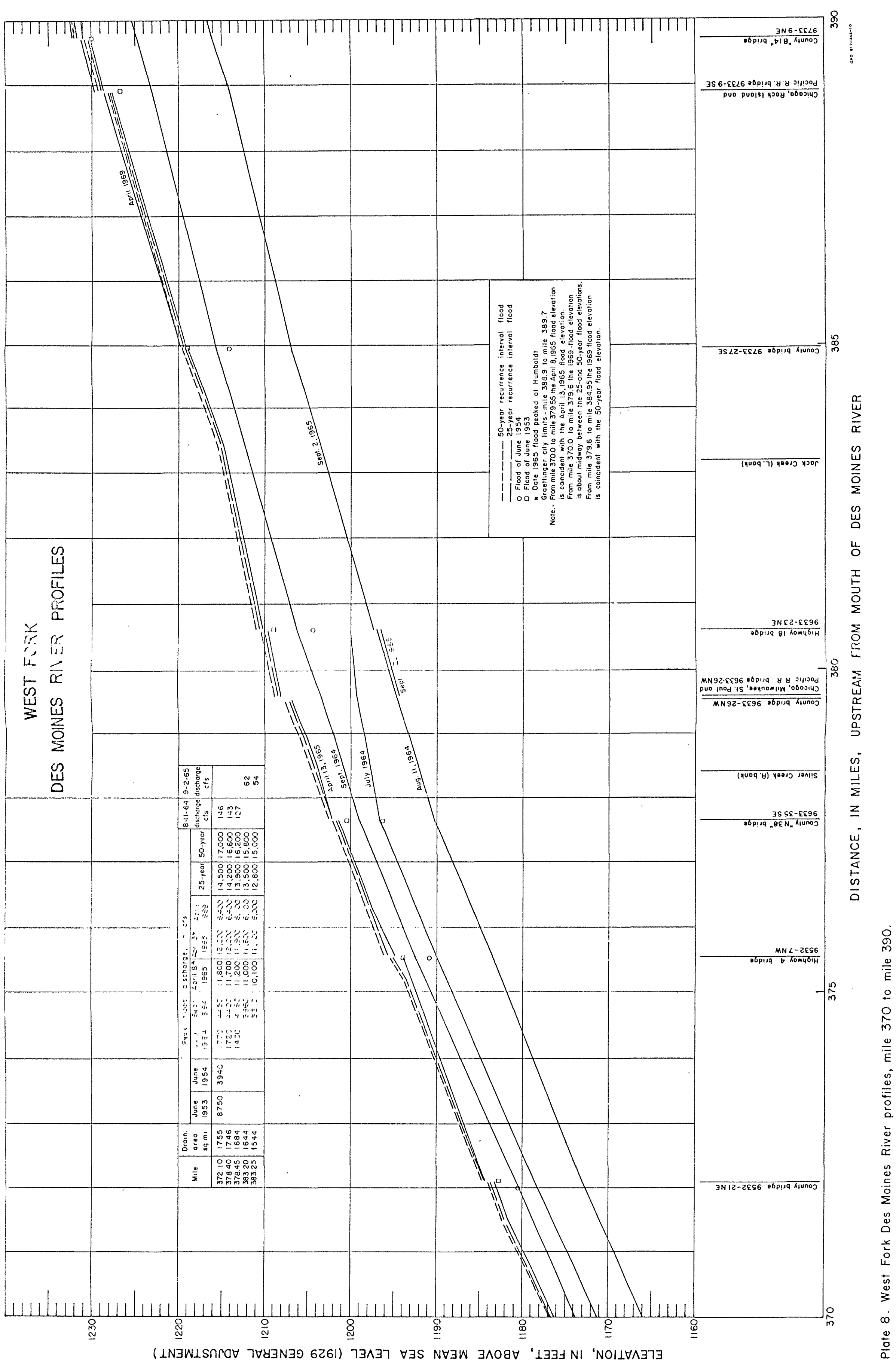




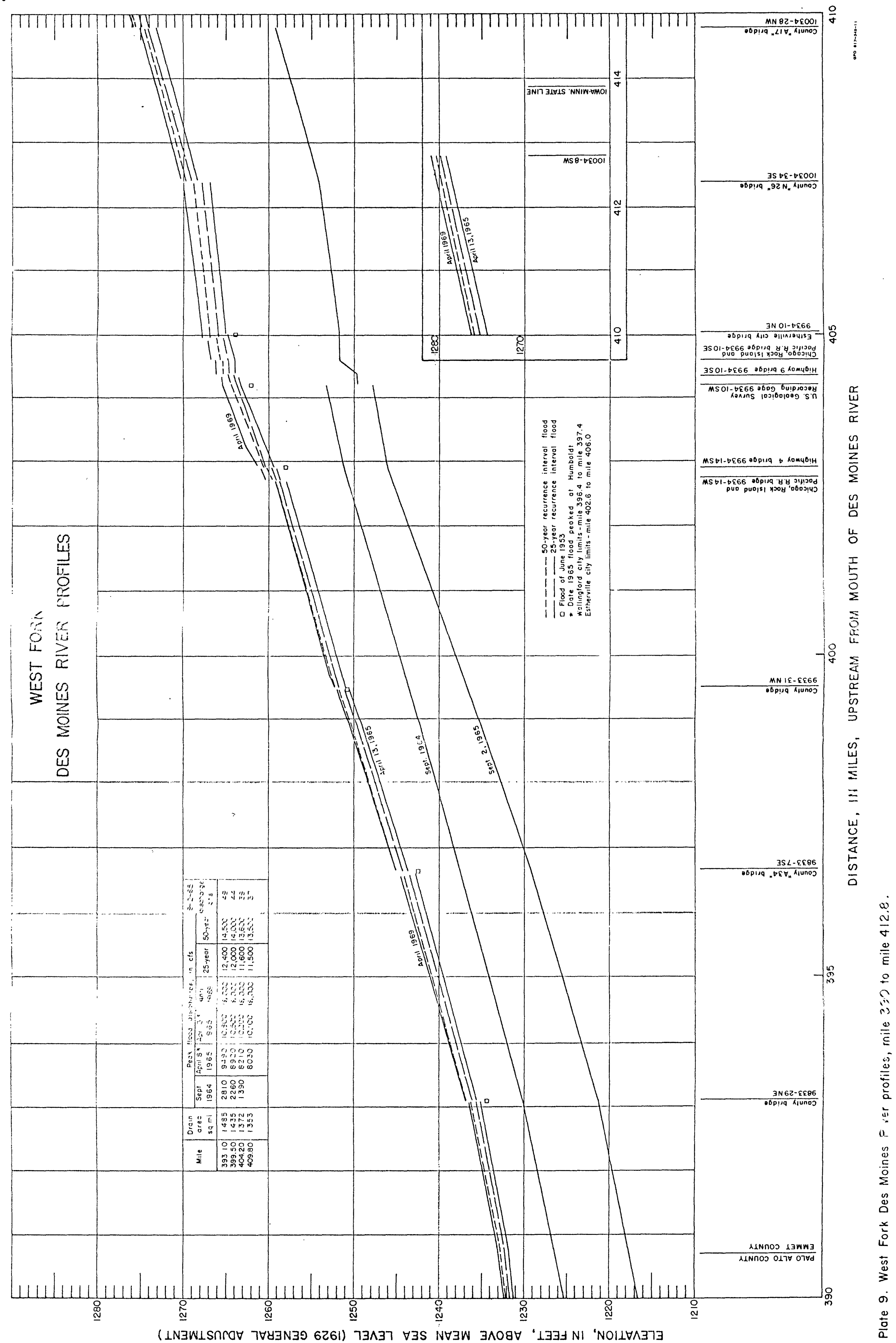




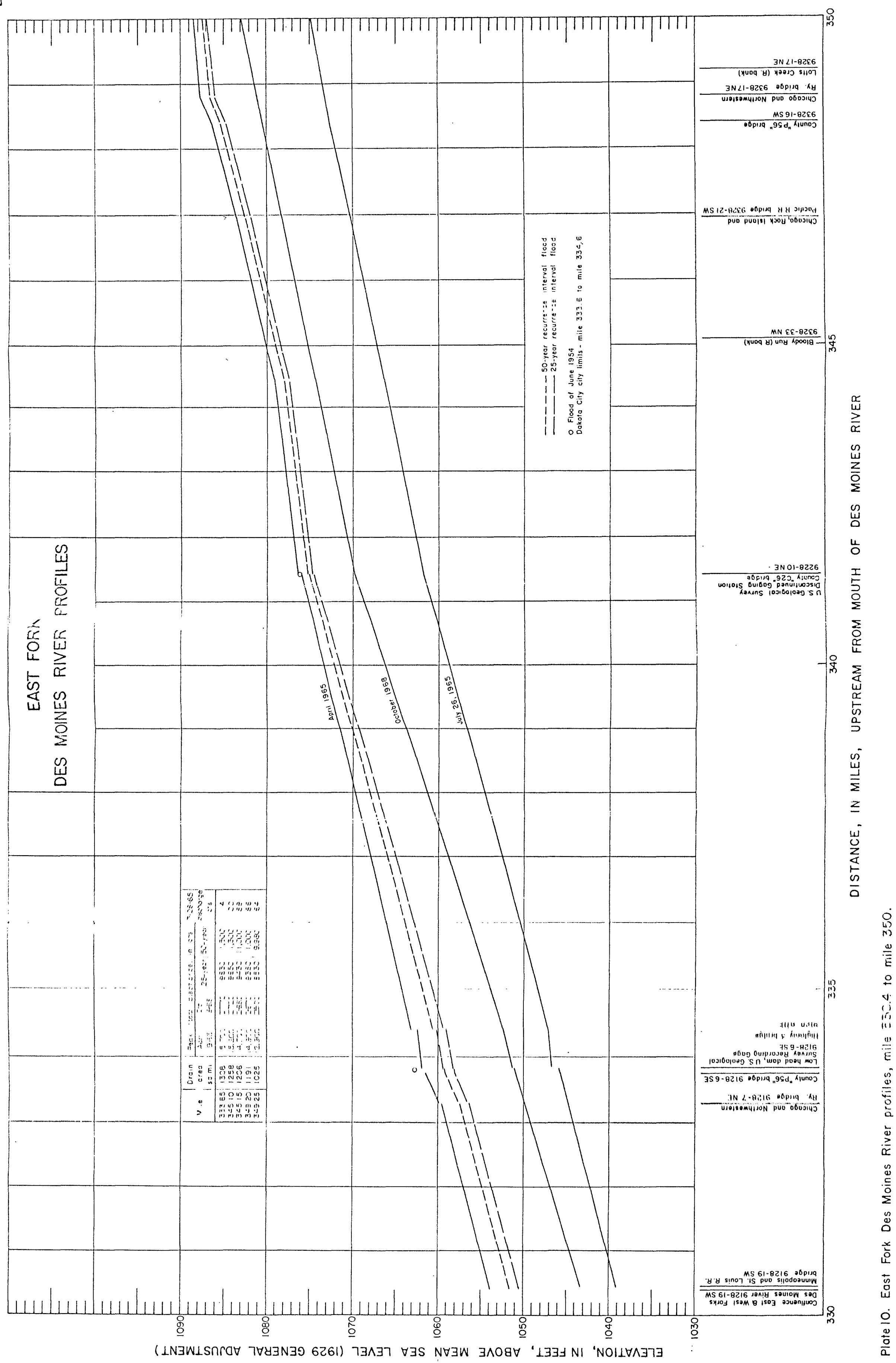




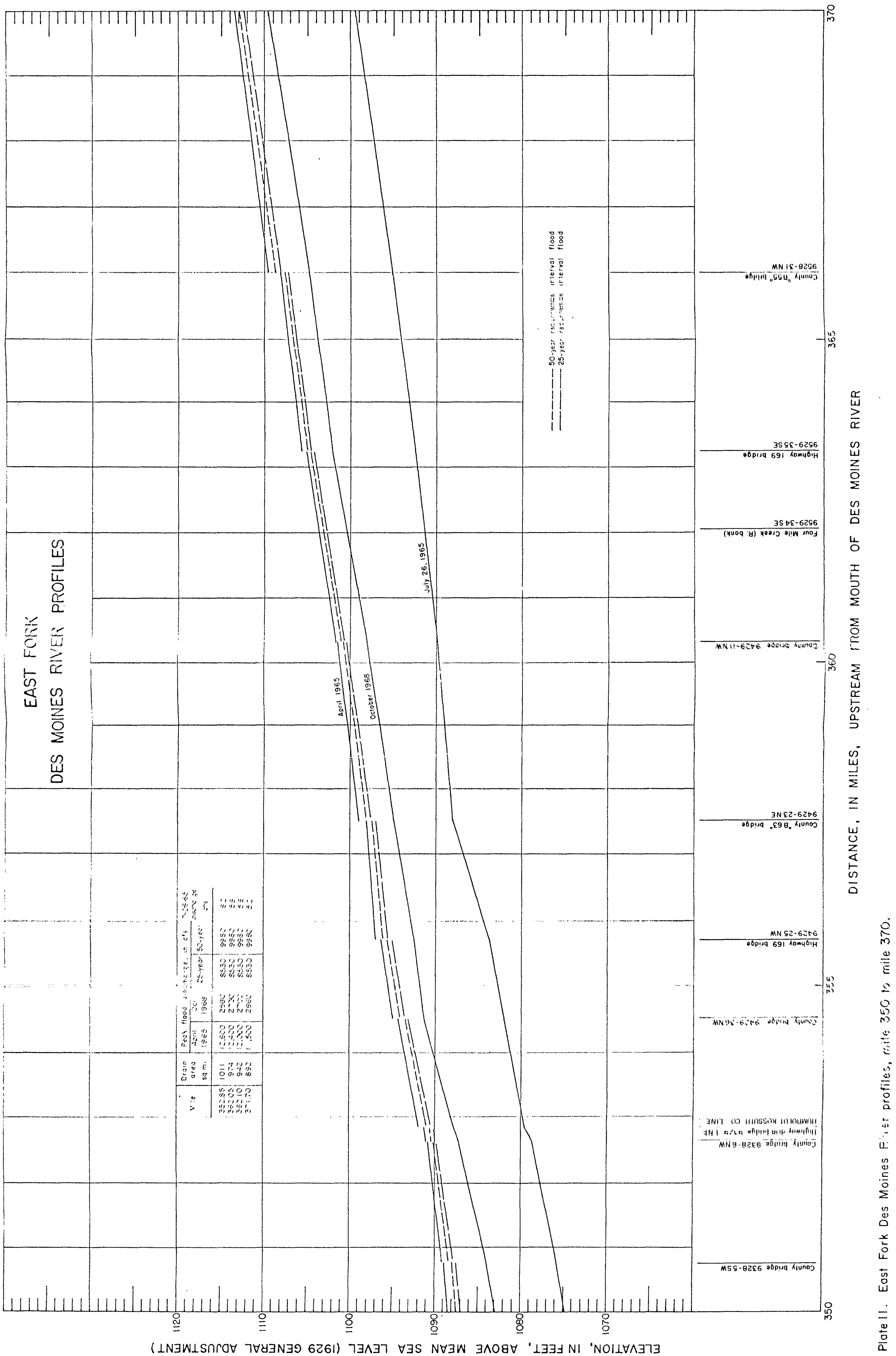


N

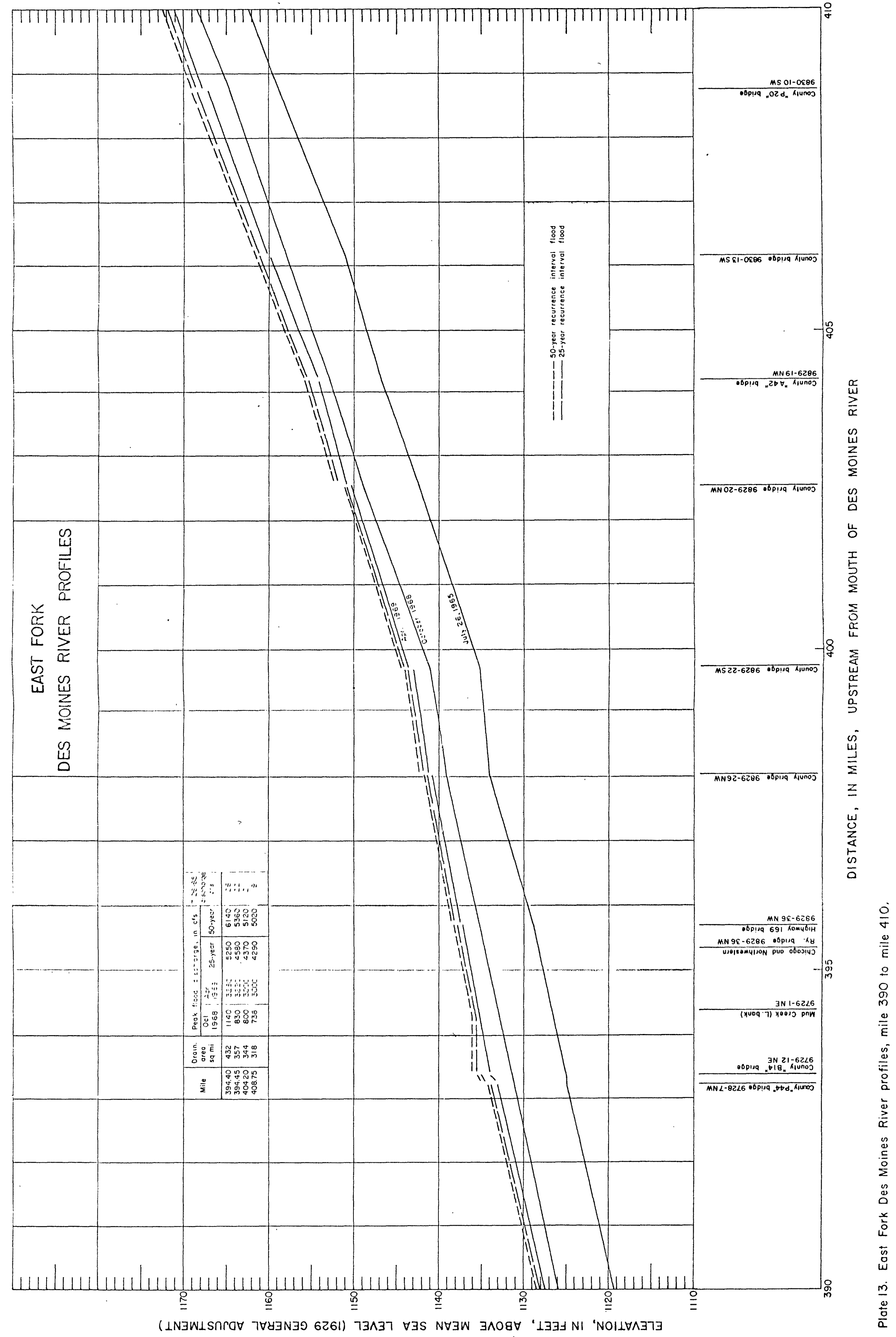


$\stackrel{\infty}{N}$

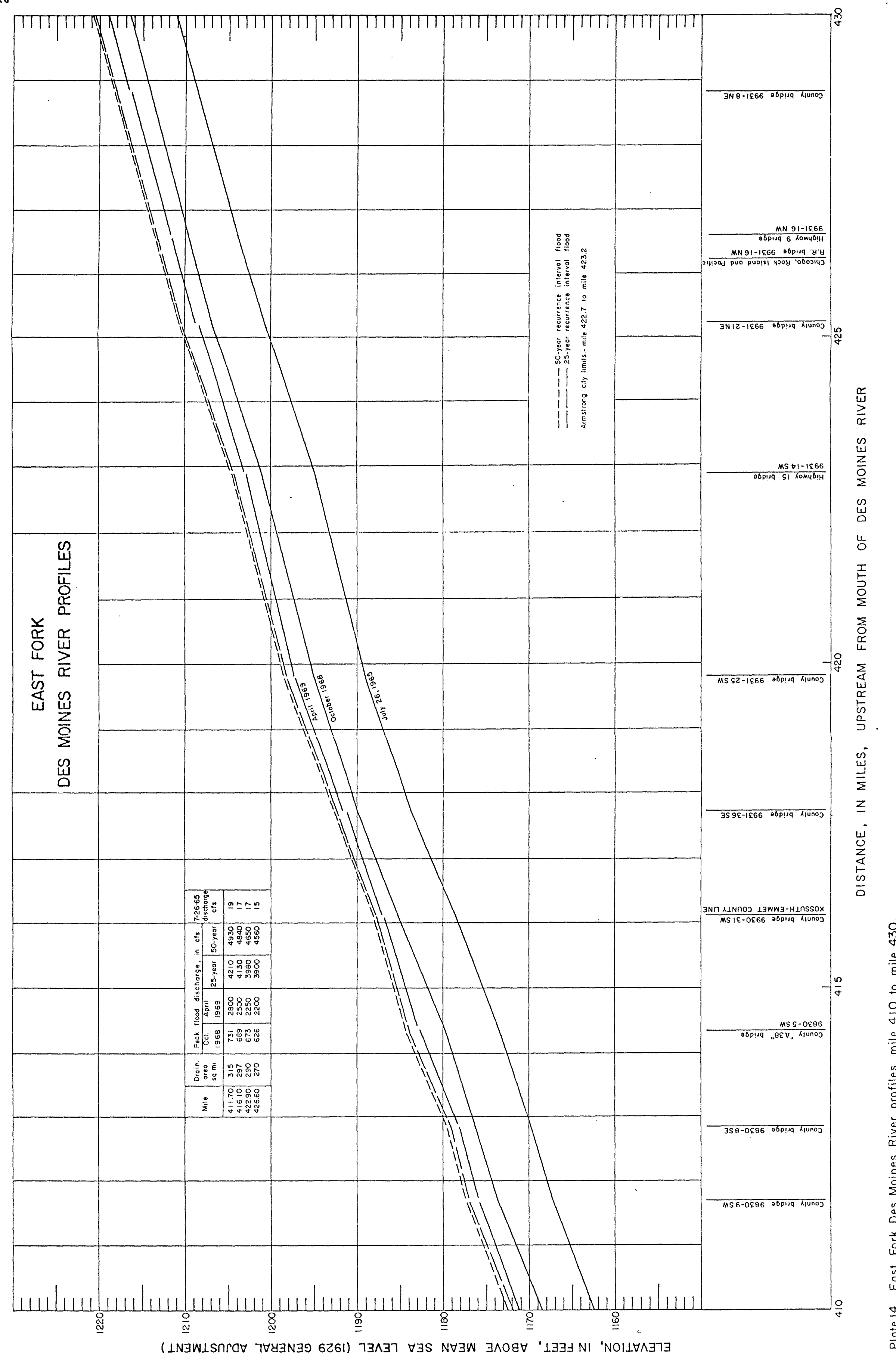


9
4
3
3
3

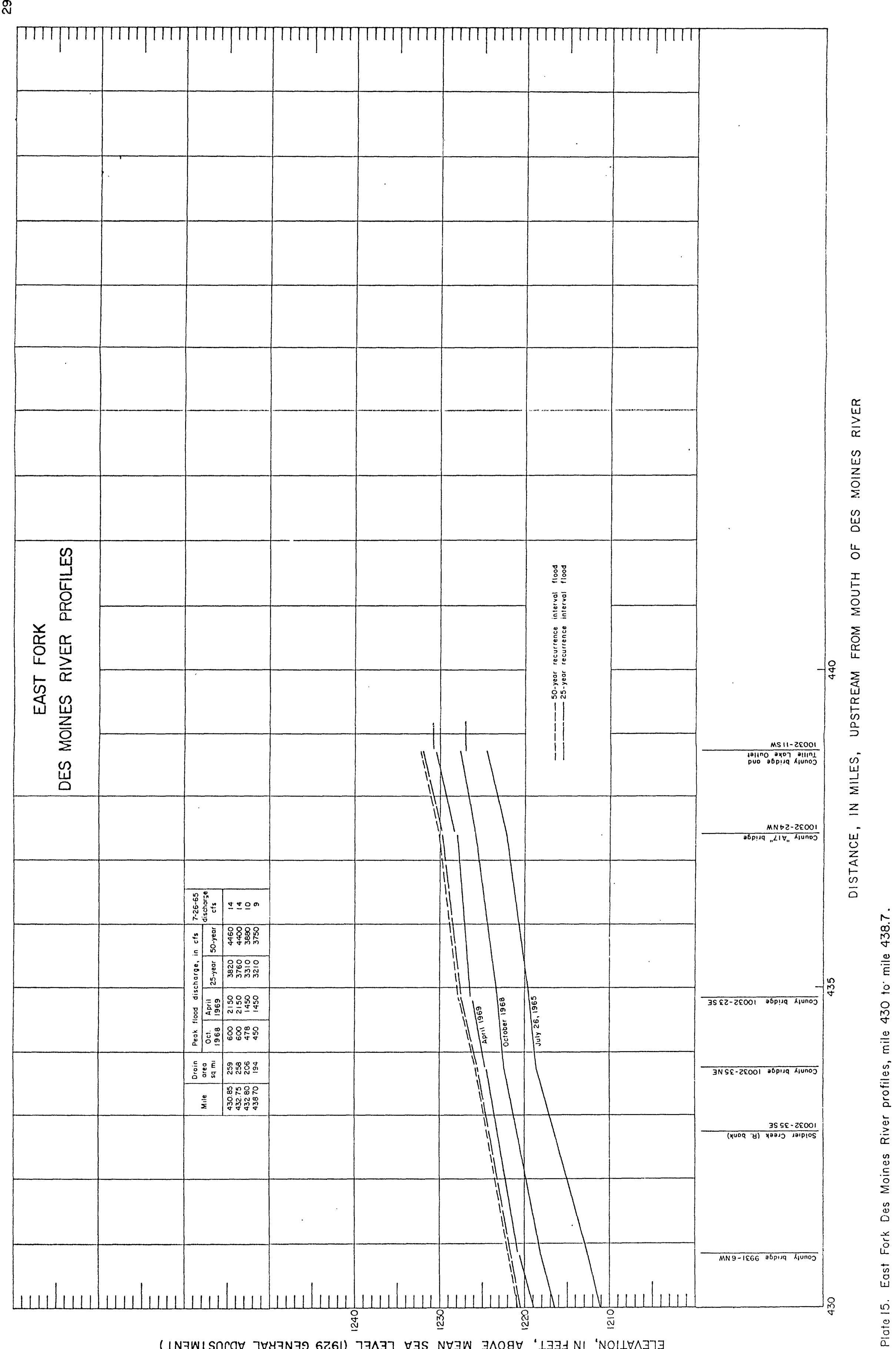




\section{DISCUSSION}

Data for 10 notable flood years in the upper Des Moines River basin are included in this report. These data in combination with the computed 25- and 50-year flood discharges and profiles provide flood information along 253 miles of streams in the basin. Information of this type can benefit nearly all activities of man occurring on the flood plain. For example, the report can furnish data on (1) the past record of flood heights and discharges, (2) the time distribution of flood elevations and discharges (for certain floods) above a selected elevation, (3) flood volumes, and (4) the frequency of past and future floods. Information for (1) is presented in the gaging-station records and on the profile sheets, for (2) and (3) in the tabulated time and discharge data in the gaging station records, (and additional references) and for (4) from the frequency data on the profile sheets and frequency curves in the report.

The elevation and discharge data on the profile sheets can be used to prepare rating curves. Such curves will represent the conditions at the time of the floods that were profiled. Significant changes in the conditions at or downstream from the selected point can change this relation. Permanent changes such as channel straightening, construction of levees, or dams will all affect the relation of elevation to discharge. Temporary changes in the relation will be caused by ice jams or debris jams that are not predictable. The effect of these jams is to cause flood elevations upstream to be higher than those for normal conditions. At many places there is only a small difference in 
elevation between the 25- and 50-year flood--often only a few tenths of a foot. This small spread in elevation occurs where a flood plain is wide and flat and relatively large changes in flood discharge cause only small changes in flood elevation.

Stage-frequency curves can be prepared from the data included in this report. The stage for a discharge of known frequency can be derived from the rating curves described in the previous paragraph. Several such determinations will furnish the data from which a stagefrequency curve can be plotted.

\section{REFERENCES}

Iowa Natural Resources Council, 1953, An inventory of water resources and water problems Des Moines River basin, Iowa: Bull. no. 1, $63 \mathrm{p}$.

Larimer, 0. J., 1957, Drainage areas of Iowa streams: Iowa Highway Research Board Bu11. no. 7, 440 p.

Schwob, H. H., 1966, Magnitude and frequency of Iowa floods: Iowa Highway Research Board Bull. no. 28, pt. 1, 47 p., pt. 2, 376 p.

U.S. Geol. Survey, issued annually, Water resources data for Iowa--part 1, surface water records: open-file reports. , 1955, Floods of June 1953 in northwestern Iowa: U.S. Geol. Survey Water-Supply Paper 1320-A, 68 p.

, is sued annually to 1960, Surface Water Supply of the United States, part 5, Hudson Bay and Upper Mississippi River basin: U.S. Geol. Survey Water-Supply Papers.

Yost, I. D., 1958, Floods of June 1954 in Iowa: U.S. Geol. Survey Water-Supply Paper 1370-A, 106 p. 
APPENDIX

The flood data which follow are for the 1965 and 1969 floods at gaging stations in the upper Des Moines River basin. Some of these data are not available in other publications.

Gaging-station records are arranged in the downstream order used by and explained in the annual reports of the U.S. Geological Survey. Since 1961 these reports have been published on an annual basis for each state. The annual reports contain much information that supplements data in this report. In particular, the reports for 1965 and 1969 will be needed in any studies involving the stream discharges of the antecedent and post flood periods.

Each gaging-station record has the assigned permanent station number preceding the station name. These numbers are also used on plate 1 and in table 2. Below the name are the station description followed by (for 5 stations) the tabulated daily mean discharges and stage-discharge hydrograph data. Four of the stations have no tabulated stage or discharge data because data were not available or the flood was small.

During periods of ice effect only daily mean discharges have been computed. Stages for specific times are tabulated for the hydrographs for these days and the discharge column is left blank. The daily mean discharge will be found in the table preceding the hydrograph tabulation. 
5-4760 West Fork Des Moines River at Jackson, Minnesota

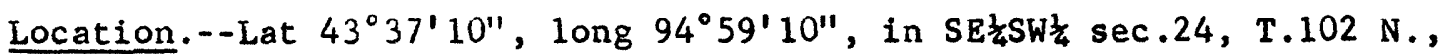
R. $35 \mathrm{~W}$., on right bank in storage room of city powerplant in Jackson.

Drainage area.--1,220 sq $\mathrm{mi}$, approximately.

Gage-height record.--Water-stage recorder graph. Datum of gage is $1,287.75 \mathrm{ft}$ above mean sea level, datum of 1929. April 1938 chain gage at site 7 miles upstream at datum $17.10 \mathrm{ft}$ higher. Oct. 1, 1944 to Oct. 26, 1949, wire-weight gage at site $600 \mathrm{ft}$ upstream at datum $10.64 \mathrm{ft}$ higher. Oct. 27, 1942, to December 15, 1965, waterstage recorder graph $200 \mathrm{ft}$ downstream at same datum.

Discharge record.--Stage-discharge relation defined by current-meter measurements.

Maxima.--April 1969: Discharge, 15,700 cfs April 11 (gage height, 19.45 $f t$ ).

Period of flood record, 1935-69 (1969 flood excluded): Discharge, 9,530 cfs, Apr. 9, 1965, maximum gage height, $18.62 \mathrm{ft} \mathrm{Apr.} \mathrm{6,} 1965$ (backwater from ice). 
5-4765 West Fork Des Moines River at Estherville, Iowa

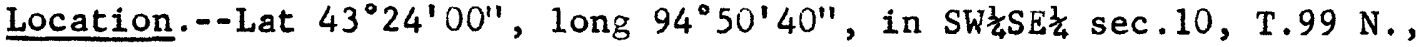
R.34 W., on right oank in city park, 1,200 ft downstream from bridge on State Highway 9 at Estherville, 2.5 miles upstream from Brown Creek, and at mile 404.2 upstream from mouth of Des Moines River.

Drainage area. $--1,372 \mathrm{sq} \mathrm{mi}$.

Gage-height record.--Digital-recorder tape punched at 15-minute intervals. Datum of gage is $1,247.55 \mathrm{ft}$ above mean sea level, datum of 1929. Prior to Mar. 27, 1966, graphic water-stage recorder chart for same site and datum.

Discharge record.--Stage-discharge relation defined by current-meter measurements. Backwater from ice Apr. 4-8, 1965, and Apr. 1-3, 1969.

Maxima.--March-May 1965: Discharge, 10,200 cfs Apr. 10 (gage height, $15.61 \mathrm{ft}$ ).

March-May 1969: Discharge, 16,000 cfs Apr. 12 (gage height, $17.68 \mathrm{ft}$ ).

Period of flood record 1951-69 (excluding 1965 and 1969): Discharge, 10,800 cfs June 8, 1953 (gage height, $15.53 \mathrm{ft}$ ).

Remarks.--Tables of daily discharges and detailed hydrographs for flood of June 1953 contained in U.S. Geological Survey Water-Supply Paper 1320-A.

Tables of daily discharges and detailed hydrograph for flood of June 1954 contained in U.S. Geological Survey Water-Supply Paper 1370-A.

Mean discharge in cubic feet per second, 1965

\begin{tabular}{|c|c|c|c|c|c|c|c|c|}
\hline Day & April & May & Day & April & May & Day & April & May \\
\hline $\begin{array}{c}\ldots \\
2 \ldots \\
3 \ldots \\
4 \ldots \\
5 \ldots \\
6 \ldots \\
7 \ldots \\
8 \ldots \\
9 \ldots \\
10 \ldots\end{array}$ & $\begin{array}{r}490 \\
1,120 \\
1,340 \\
1,660 \\
3,000 \\
5,700 \\
7,200 \\
7,600 \\
7,860 \\
9,660\end{array}$ & $\begin{array}{l}1,810 \\
1,670 \\
1,540 \\
1,490 \\
1,660 \\
1,400 \\
1,390 \\
1,790 \\
1,760 \\
1,900\end{array}$ & $\begin{array}{l}11 \ldots \\
12 \ldots \\
13 \ldots \\
14 \ldots \\
15 \ldots \\
16 \ldots \\
17 \ldots \\
18 \ldots \\
19 \ldots \\
20 \ldots\end{array}$ & $\begin{array}{l}9,490 \\
8,300 \\
7,000 \\
6,060 \\
5,530 \\
4,980 \\
4,380 \\
3,960 \\
3,680 \\
3,380\end{array}$ & $\begin{array}{l}2,090 \\
1,790 \\
1,620 \\
1,670 \\
1,880 \\
2,070 \\
1,930 \\
1,800 \\
1,730 \\
1,730\end{array}$ & $\begin{array}{l}21 \ldots \\
22 \ldots \\
23 \ldots \\
24 \ldots \\
25 \ldots \\
26 \ldots \\
27 \ldots \\
28 \ldots \\
29 \ldots \\
30 \ldots \\
31 \ldots\end{array}$ & $\begin{array}{l}3,100 \\
2,760 \\
2,490 \\
2,360 \\
2,340 \\
2,390 \\
2,410 \\
2,320 \\
2,140 \\
1,940 \\
\ldots-.\end{array}$ & $\begin{array}{l}1,960 \\
2,110 \\
1,940 \\
1,800 \\
1,980 \\
2,180 \\
2,160 \\
2,010 \\
1,880 \\
1,860 \\
1,850\end{array}$ \\
\hline \multicolumn{7}{|c|}{ 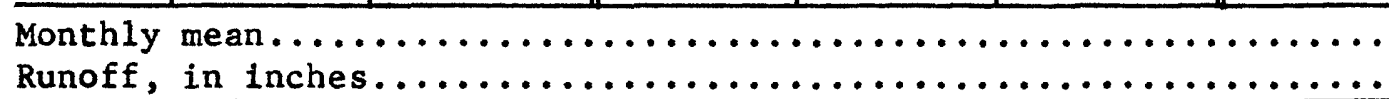 } & $\begin{array}{r}4,221 \\
3.43 \\
\end{array}$ & $\begin{array}{r}1,821 \\
1.53 \\
\end{array}$ \\
\hline
\end{tabular}


West Fork Des Moines River at Estherville, Iowa--Continued

Gage height, in feet, and discharge in cubic feet per second at indicated time, 1965

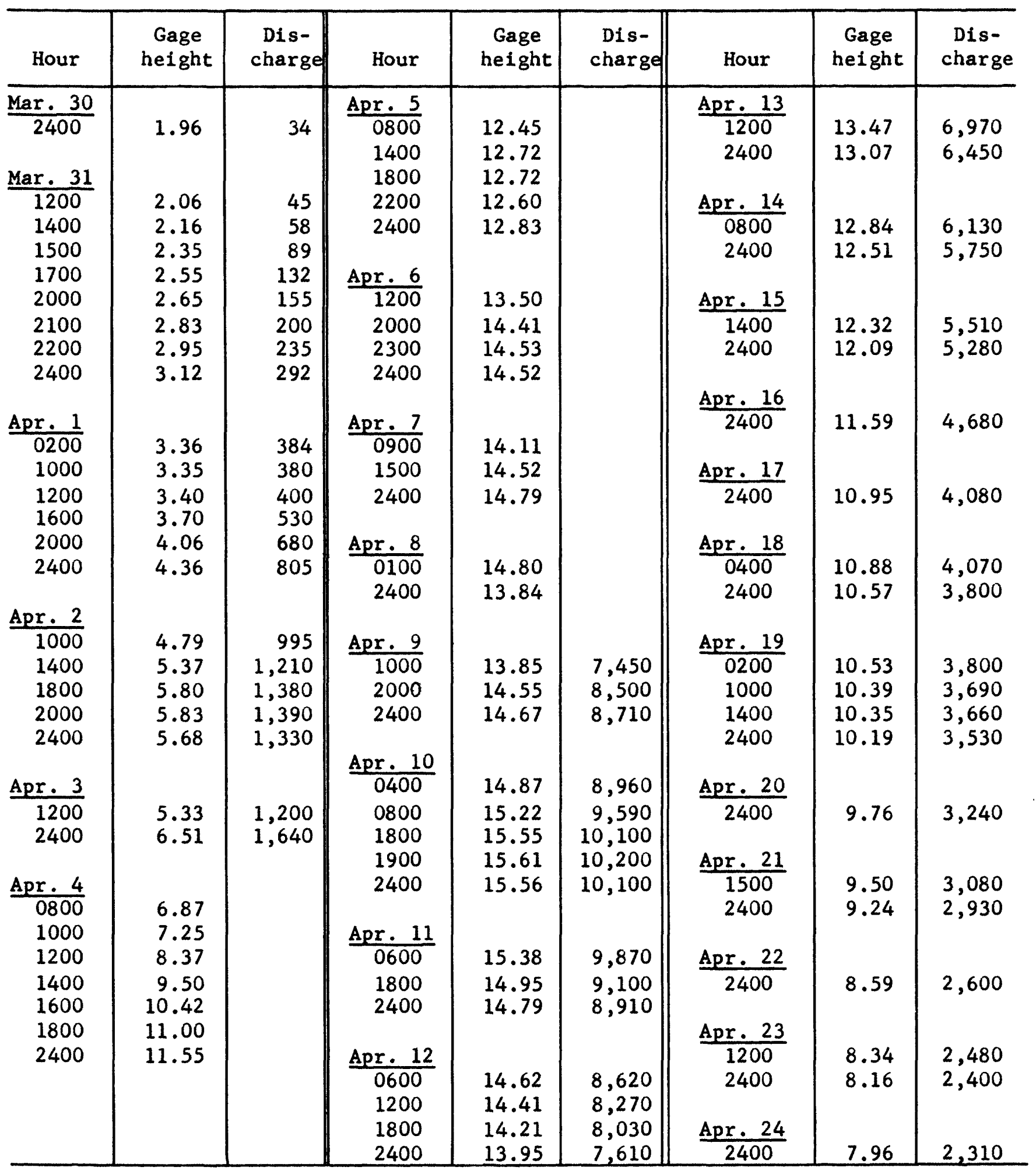


West Fork Des Moines River at Estherville, Iowa--Continued

Mean discharge, in cubic feet per second, 1969

\begin{tabular}{|c|c|c|c|c|c|c|c|}
\hline Day & April & Day & April & Day & April & Day & April \\
\hline $\begin{array}{l}1 \ldots \ldots \\
2 \ldots \ldots\end{array}$ & $\begin{array}{l}485 \\
630\end{array}$ & $\begin{array}{l}8 \ldots \\
9 \ldots\end{array}$ & $\begin{array}{r}7,250 \\
10,700\end{array}$ & $\begin{array}{l}15 \ldots \\
16 \ldots\end{array}$ & $\begin{array}{r}10,500 \\
9,370\end{array}$ & $\begin{array}{l}23 \ldots \ldots \\
24 \ldots\end{array}$ & $\begin{array}{l}4,200 \\
3,730\end{array}$ \\
\hline $\begin{array}{l}3 \ldots \ldots \\
4 \ldots \ldots \\
5 \ldots \ldots \\
6 \ldots \ldots \\
7 \ldots \ldots\end{array}$ & $\begin{array}{r}900 \\
1,920 \\
3,010 \\
4,150 \\
5,620\end{array}$ & $\begin{array}{l}10 \ldots \\
11 \ldots \\
12 \ldots \\
13 \ldots \\
14 \ldots\end{array}$ & $\begin{array}{l}13,700 \\
15,600 \\
15,800 \\
14,400 \\
12,200\end{array}$ & $\begin{array}{l}17 \ldots \ldots \\
18 \ldots \\
19 \ldots \\
20 \ldots \\
21 \ldots \\
22 \ldots\end{array}$ & $\begin{array}{l}8,160 \\
7,120 \\
6,290 \\
5,660 \\
5,160 \\
4,730 \\
\end{array}$ & $\begin{array}{l}25 \ldots \ldots \\
26 \ldots \ldots \\
27 \ldots \ldots \\
28 \ldots \\
29 \ldots \\
30 \ldots\end{array}$ & $\begin{array}{l}3,520 \\
3,320 \\
3,150 \\
2,950 \\
2,760 \\
2,580 \\
\end{array}$ \\
\hline $\begin{array}{l}\text { onthly } \\
\text { unoff }\end{array}$ & & & & & & & $\begin{array}{r}6,320 \\
5.14 \\
\end{array}$ \\
\hline
\end{tabular}

Gage height, in feet, and discharge, in cubic feet per second

\begin{tabular}{|c|c|c|c|c|c|c|c|c|}
\hline Hour & $\begin{array}{c}\text { Gage } \\
\text { height }\end{array}$ & $\begin{array}{c}\text { Dis- } \\
\text { charge }\end{array}$ & Hour & $\begin{array}{c}\text { Gage } \\
\text { height }\end{array}$ & $\begin{array}{c}\text { Dis- } \\
\text { charge }\end{array}$ & Hour & $\begin{array}{c}\text { Gage } \\
\text { height }\end{array}$ & $\begin{array}{l}\text { Dis- } \\
\text { charge }\end{array}$ \\
\hline $\begin{array}{r}\text { Apr. } 2 \\
2400 \\
\text { Apr. } 3 \\
1200 \\
1800 \\
2400 \\
\text { Apr. } 4 \\
0600 \\
1200 \\
1800 \\
2400 \\
\\
\text { Apr. } 5 \\
0600 \\
1200 \\
1800 \\
2400 \\
\\
\text { Apr. } 6 \\
0600 \\
1200 \\
1800 \\
2400\end{array}$ & $\begin{array}{r}8.79 \\
9.07 \\
9.97 \\
10.30\end{array}$ & $\begin{array}{l}2,710 \\
2,850 \\
3,380 \\
3.610 \\
\\
3,550 \\
4,160 \\
4,650 \\
5,020\end{array}$ & $\begin{array}{c}\text { Apr. } 7 \\
0600 \\
1200 \\
1800 \\
2400 \\
\text { Apr. } 8 \\
0600 \\
1200 \\
1800 \\
2400 \\
\\
\text { Apr. } 9 \\
0600 \\
1200 \\
1800 \\
2400 \\
\\
\text { Apr. } 10 \\
0600 \\
1200 \\
1800 \\
2400 \\
\\
\text { Apr. } 11 \\
0600 \\
1200 \\
1800 \\
2400\end{array}$ & $\begin{array}{l}16.82 \\
17.02 \\
17.20 \\
17.35\end{array}$ & $\begin{array}{l}13,100 \\
13,700 \\
14,400 \\
14,900\end{array}$ & $\begin{array}{c}\text { Apr. } 12 \\
0300 \\
0600 \\
1200 \\
1800 \\
2400 \\
\text { Apr. } 13 \\
0600 \\
1200 \\
1800 \\
2400 \\
\text { Apr. } 14 \\
1200 \\
2400 \\
\text { Apr. } 15 \\
1200 \\
2400 \\
\text { Apr. } 16 \\
1200 \\
2400 \\
\text { Apr. } 17 \\
1200 \\
2400\end{array}$ & $\begin{array}{l}17.68 \\
17.67 \\
17.65 \\
17.58 \\
17.48\end{array}$ & $\begin{array}{l}16,000 \\
16,000 \\
15,900 \\
15,700 \\
15,300\end{array}$ \\
\hline
\end{tabular}


5-4767.5 West Fork Des Moines River at Humboldt, Iowa

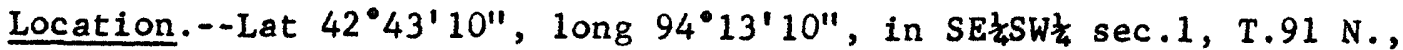
R.29 W., at First Avenue Bridge in City of Humboldt, about 700 ft below dam, 3.9 miles upstream from confluence with East Fork Des Moines River, and at mile 334.3 upstream from mouth of Des Moines River.

Drainage area. $--2,256 \mathrm{sq} \mathrm{mi}$.

Gage-height record.--Digital-recorder tape punched at 15-minute intervals. Prior to 0ct. 3, 1966, wire-weight gage at same site and datum.

Discharge record.--Stage-discharge relation defined by current-meter measurements. Prior to 0ct. 3, 1966, discharges computed from graph of wire-weight gage readings.

Maxima.--March-May 1965: Discharge, 14,400 cfs Apr. 8 (gage height, $13.90 \mathrm{ft}$ ).

March-May 1969: Discharge, 18,000 cfs Apr. 14, 1969 (gage height $15.40 \mathrm{ft}$ ).

Period of flood record, 1940-69 (excluding 1965 and 1969 floods): Discharge, 11,000 cfs June 23, 1947 (gage height $12.2 \mathrm{ft}$ ).

Remarks.--Tables of daily discharges and detailed hydrograph for flood of June 1953 contained in U.S. Geological Survey Water-Supply Paper 1320-A.

Detailed hydrograph for flood of June 1954 contained in U.S. Geological Survey Water-Supply Paper 1370-A. Daily discharge not published for June 1954 flood because of extreme regulation of streamflow by Iowa Public Service Company power dam $700 \mathrm{ft}$ upstream from gage. Power generation and streamflow regulation discontinued August 1964.

Mean discharge in cubic feet per second, 1965

\begin{tabular}{|c|c|c|c|c|c|c|c|c|}
\hline Day & April & May & Day & April & May & Day & April & May \\
\hline $\begin{array}{c}1 \ldots \\
2 \ldots \\
3 \ldots \\
4 \ldots \\
5 \ldots \\
6 \ldots \\
7 \ldots \\
8 \ldots \\
9 \ldots \\
10 \ldots\end{array}$ & $\begin{array}{r}1,520 \\
2,150 \\
2,920 \\
4,600 \\
7,330 \\
9,340 \\
12,500 \\
14,300 \\
14,000 \\
13,700\end{array}$ & $\begin{array}{l}3,610 \\
3,340 \\
3,040 \\
2,830 \\
2,600 \\
2,510 \\
2,540 \\
2,560 \\
2,560 \\
2,860\end{array}$ & $\begin{array}{l}11 \ldots \\
12 \ldots \\
13 \ldots \\
14 \ldots \\
15 \ldots \\
16 \ldots \\
17 \ldots \\
18 \ldots \\
19 \ldots \\
20 \ldots\end{array}$ & $\begin{array}{r}12,700 \\
12,200 \\
13,400 \\
12,800 \\
11,700 \\
10,500 \\
9,260 \\
8,420 \\
7,650 \\
6,980\end{array}$ & $\begin{array}{l}3,100 \\
3,010 \\
2,850 \\
2,730 \\
2,610 \\
2,790 \\
3,160 \\
3,280 \\
3,170 \\
2,950\end{array}$ & $\begin{array}{l}21 \ldots \\
22 \ldots \\
23 \ldots \\
24 \ldots \\
25 \ldots \\
26 \ldots \\
27 \ldots \\
28 \ldots \\
29 \ldots \\
30 \ldots \\
31 \ldots\end{array}$ & $\begin{array}{c}6,370 \\
5,740 \\
5,210 \\
4,910 \\
4,670 \\
4,460 \\
4,410 \\
4,160 \\
3,920 \\
3,780 \\
\ldots\end{array}$ & $\begin{array}{l}2,740 \\
2,660 \\
2,680 \\
2,860 \\
3,140 \\
3,440 \\
3,360 \\
3,560 \\
3,530 \\
3,360 \\
3,170\end{array}$ \\
\hline \multicolumn{7}{|c|}{$\begin{array}{l}\text { Monthly }{ }^{2}{ }_{10} \\
\text { Runoff, }\end{array}$} & $\begin{array}{r}7,853 \\
3.88\end{array}$ & $\begin{array}{r}2,987 \\
1.53\end{array}$ \\
\hline
\end{tabular}


West Fork Des Moines River at Humboldt, Iowa--Continued

Gage height, in feet, and discharge in cubic feet per second at indicated time, 1965

\begin{tabular}{|c|c|c|c|c|c|c|c|c|}
\hline Hour & $\begin{array}{c}\text { Gage } \\
\text { height }\end{array}$ & $\begin{array}{l}\text { Dis- } \\
\text { charge }\end{array}$ & Hour & $\begin{array}{c}\text { Gage } \\
\text { height }\end{array}$ & $\begin{array}{l}\text { Dis- } \\
\text { charge }\end{array}$ & Hour & $\begin{array}{c}\text { Gage } \\
\text { height }\end{array}$ & $\begin{array}{l}\text { Dis- } \\
\text { charge }\end{array}$ \\
\hline $\begin{array}{l}\frac{\text { Mar. } 30}{2400} \\
\text { Mar. } 31 \\
\end{array}$ & 3.47 & 276 & $\begin{array}{r}\text { Apr. } 7 \\
0600 \\
1000 \\
2400\end{array}$ & $\begin{array}{l}12.52 \\
12.57 \\
13.64\end{array}$ & $\begin{array}{l}12,000 \\
12,100 \\
14,000\end{array}$ & $\begin{array}{c}\text { Apr. } 16 \\
0800 \\
2400\end{array}$ & $\begin{array}{l}11.78 \\
11.33\end{array}$ & $\begin{array}{r}10,700 \\
9,770\end{array}$ \\
\hline $\begin{array}{l}1000 \\
1400\end{array}$ & $\begin{array}{l}3.60 \\
3.87\end{array}$ & $\begin{array}{l}335 \\
478\end{array}$ & Apr .8 & & & $\frac{\text { Apr. } 17}{1200}$ & 11.02 & 9,220 \\
\hline $\begin{array}{l}1800 \\
2200\end{array}$ & $\begin{array}{l}4.09 \\
4.40\end{array}$ & $\begin{array}{l}609 \\
820\end{array}$ & $\begin{array}{l}1200 \\
1400\end{array}$ & $\begin{array}{l}13.88 \\
13.90\end{array}$ & $\begin{array}{l}14,400 \\
14,400\end{array}$ & 2400 & 10.80 & 8,820 \\
\hline 2400 & 4.56 & 932 & $\begin{array}{l}1800 \\
2400\end{array}$ & $\begin{array}{l}13.89 \\
13.76\end{array}$ & $\begin{array}{l}14,400 \\
14,200\end{array}$ & $\frac{\text { Apr. } 18}{2400}$ & 10.36 & 8,030 \\
\hline$\frac{\text { Apr. } 1}{0400}$ & 4.99 & 1,260 & Apr. 9 & & & Apr. 19 & & \\
\hline 0600 & 5.12 & 1,370 & 0800 & 13.60 & 13,900 & 1600 & 10.07 & 7,510 \\
\hline $\begin{array}{l}1200 \\
1800\end{array}$ & $\begin{array}{l}5.38 \\
5.56\end{array}$ & $\begin{array}{l}1,570 \\
1,730\end{array}$ & 2400 & 13.65 & 14,000 & 2400 & 9.96 & 7,310 \\
\hline 2400 & 5.71 & 1,870 & $\frac{\text { Apr. } 10}{0800}$ & 13.62 & 13,900 & $\frac{\text { Apr. } 20}{1600}$ & 9.71 & 6,860 \\
\hline Apr. 2 & & & 1200 & 13.55 & 13,800 & 2400 & 9.62 & 6,700 \\
\hline $\begin{array}{l}1200 \\
2400\end{array}$ & $\begin{array}{l}6.00 \\
6.35\end{array}$ & $\begin{array}{l}2,130 \\
2,470\end{array}$ & 2400 & 13.23 & 13,200 & $\frac{\text { Apr. } 21}{2400}$ & 9.24 & \\
\hline Apr. 3 & & & $\frac{1400}{1400}$ & 12.82 & 12,500 & & & \\
\hline $\begin{array}{l}1200 \\
2400\end{array}$ & $\begin{array}{l}6.73 \\
7.33\end{array}$ & $\begin{array}{l}2,850 \\
3,490\end{array}$ & 2400 & 12.68 & 12,300 & $\frac{\text { Apr. } 22}{2400}$ & 8.86 & 5,440 \\
\hline Apr. 4 & & & $\frac{\text { Apr. } 12}{0800}$ & 12.56 & 12,100 & Apr. 23 & & \\
\hline 1200 & 8.24 & 4,570 & 1200 & 12.57 & 12,100 & 1200 & 8.69 & 5,190 \\
\hline 2400 & 9.06 & 5,760 & $\begin{array}{l}2000 \\
2400\end{array}$ & $\begin{array}{l}12.73 \\
12.86\end{array}$ & $\begin{array}{l}12,400 \\
12,600\end{array}$ & 2400 & 8.58 & 5,030 \\
\hline$\frac{\text { Apr. } 5}{1200}$ & 9.90 & 7,200 & Apr 13 & & & $\frac{\text { Apr. } 24}{2400}$ & 8.41 & 4,790 \\
\hline 1600 & 10.15 & 7,650 & 1000 & 13.44 & 13,600 & & & \\
\hline 1800 & 11.10 & 9,360 & 1500 & 13.43 & 13,600 & Apr. 25 & & \\
\hline 2000 & 10.60 & 8,460 & 2400 & 13.33 & 13,400 & 2400 & 8.23 & 4,560 \\
\hline $\begin{array}{r}2400 \\
\text { Apr. } 6 \\
\end{array}$ & 10.55 & 8,370 & $\frac{\text { Apr. } 14}{1000}$ & 13.10 & 13,000 & $\frac{\text { Apr. } 26}{0600}$ & 8.17 & 4,480 \\
\hline $\begin{array}{l}0400 \\
1200 \\
1800 \\
2400\end{array}$ & $\begin{array}{l}10.59 \\
10.96 \\
11.52 \\
11.85\end{array}$ & $\begin{array}{r}8,440 \\
9,110 \\
10,100 \\
10,800\end{array}$ & $\begin{array}{c}2400 \\
\text { Apr. } 15 \\
\begin{array}{l}1200 \\
2400\end{array}\end{array}$ & $\begin{array}{l}12.33 \\
12.08\end{array}$ & $\begin{array}{l}11,700 \\
11,200\end{array}$ & 2400 & 8.10 & 4,400 \\
\hline
\end{tabular}


West Fork Des Moines River at Humboldt, Iowa--Continued

Mean discharge, in cubic feet per second, 1969

\begin{tabular}{|c|c|c|c|c|c|c|c|}
\hline Day & April & Day & April & Day & Apri1 & Day & April \\
\hline $\begin{array}{l}\ldots \ldots \\
2 \ldots \ldots \\
3 \ldots \ldots \\
4 \ldots \ldots \\
5 \ldots \ldots \\
6 \ldots \ldots \\
7 \ldots \ldots\end{array}$ & $\begin{array}{l}2,680 \\
2,570 \\
2,930 \\
4,140 \\
4,700 \\
5,410 \\
5,720\end{array}$ & $\begin{array}{c}8 \ldots \\
9 \ldots \\
10 \ldots \\
11 \ldots \\
12 \ldots \\
13 \ldots \\
14 \ldots\end{array}$ & $\begin{array}{r}5,860 \\
6,110 \\
6,650 \\
8,160 \\
12,600 \\
16,400 \\
17,800\end{array}$ & $\begin{array}{l}15 \ldots \\
16 \ldots \\
17 \ldots \\
18 \ldots \\
19 \ldots \\
20 \ldots \\
21 \ldots \\
22 \ldots\end{array}$ & $\begin{array}{r}17,600 \\
16,400 \\
14,900 \\
13,400 \\
11,800 \\
10,700 \\
9,310 \\
8,440 \\
\end{array}$ & $\begin{array}{l}23 \ldots \ldots \\
24 \ldots \ldots \\
25 \ldots \ldots \\
26 \ldots \\
27 \ldots \ldots \\
28 \ldots \\
29 \ldots \\
30 \ldots \\
\end{array}$ & $\begin{array}{l}7,740 \\
7,080 \\
6,700 \\
6,360 \\
5,940 \\
5,540 \\
5,130 \\
4,860 \\
\end{array}$ \\
\hline
\end{tabular}

Gage height, in feet, and discharge, in cubic feet per second at indicated time, 1969

\begin{tabular}{|c|c|c|c|c|c|c|c|c|}
\hline Hour & $\begin{array}{c}\text { Gage } \\
\text { height }\end{array}$ & $\begin{array}{l}\text { Dis- } \\
\text { charge }\end{array}$ & Hour & $\begin{array}{c}\text { Gage } \\
\text { height }\end{array}$ & $\begin{array}{l}\text { Dis- } \\
\text { charge }\end{array}$ & Hour & $\begin{array}{l}\text { Gage } \\
\text { height }\end{array}$ & $\begin{array}{l}\text { Dis- } \\
\text { charge }\end{array}$ \\
\hline$\frac{\text { Apr. } 2}{2400}$ & 6.46 & 2,680 & $\begin{array}{r}\text { Apr. } 8 \\
1200 \\
2400\end{array}$ & $\begin{array}{l}8.95 \\
9.04\end{array}$ & $\begin{array}{l}5,830 \\
5,960\end{array}$ & 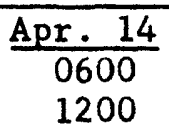 & $\begin{array}{l}15.27 \\
15.35\end{array}$ & $\begin{array}{l}17,700 \\
17,900\end{array}$ \\
\hline$\frac{\text { Apr. } 3}{0600}$ & 6.43 & 2,650 & Apr. 9 & & & $\begin{array}{l}2000 \\
2400\end{array}$ & $\begin{array}{l}15.40 \\
15.38\end{array}$ & $\begin{array}{l}18,000 \\
18,000\end{array}$ \\
\hline 1200 & 6.70 & 2,940 & 1200 & 9.13 & 6,100 & & & \\
\hline 1800 & 6.90 & 3,160 & 2400 & 9.20 & 6,200 & Apr. 15 & & \\
\hline 2400 & 7.14 & 3,430 & Apr. 10 & & & $\begin{array}{l}0600 \\
1200\end{array}$ & $\begin{array}{l}15.31 \\
15.22\end{array}$ & $\begin{array}{l}17,800 \\
17,600\end{array}$ \\
\hline Apr. 4 & & & 1200 & 9.48 & 6,620 & 1800 & 15.12 & 17,400 \\
\hline $\begin{array}{l}0600 \\
1200\end{array}$ & $\begin{array}{l}7.61 \\
7.95\end{array}$ & $\begin{array}{l}4,000 \\
4,450\end{array}$ & 2400 & 9.82 & 7,130 & 2400 & 14.99 & 17,000 \\
\hline 1800 & 7.84 & 4,300 & Apr. 11 & & & Apr. 16 & & \\
\hline 2400 & 7.82 & 4,280 & $\begin{array}{l}0600 \\
1200\end{array}$ & $\begin{array}{l}10.08 \\
10.38\end{array}$ & $\begin{array}{l}7,520 \\
8,020\end{array}$ & $\begin{array}{l}0600 \\
1200\end{array}$ & $\begin{array}{l}14.85 \\
14.70\end{array}$ & $\begin{array}{l}16,700 \\
16,400\end{array}$ \\
\hline Apr. 5 & & & 1800 & 10.81 & 8,770 & 1800 & 14.53 & 16,100 \\
\hline $\begin{array}{l}0600 \\
1200\end{array}$ & $\begin{array}{l}7.97 \\
8.17\end{array}$ & $\begin{array}{l}4,470 \\
4,730\end{array}$ & 2400 & 11.34 & 9,700 & 2400 & 14.33 & 15,700 \\
\hline 1800 & 8.34 & 4,950 & Apr. 12 & & & Apr. 17 & & \\
\hline 2400 & 8.48 & 5,130 & $\begin{array}{l}0600 \\
1200\end{array}$ & $\begin{array}{l}12.02 \\
12.83\end{array}$ & $\begin{array}{l}11,000 \\
12,700\end{array}$ & $\begin{array}{l}1200 \\
2400\end{array}$ & $\begin{array}{l}13.97 \\
13.58\end{array}$ & $\begin{array}{l}14,900 \\
14,200\end{array}$ \\
\hline Apr. 6 & & & 1800 & 13.55 & 14,100 & & & \\
\hline 1200 & 8.67 & 5,410 & 2400 & 14.02 & 15,000 & Apr. 18 & & \\
\hline 2400 & 8.81 & 5,620 & Apr. 13 & & & $\begin{array}{l}1200 \\
2400\end{array}$ & $\begin{array}{l}13.21 \\
12.81\end{array}$ & $\begin{array}{l}13,400 \\
12,600\end{array}$ \\
\hline Apr. 7 & & & 0400 & 14.32 & 15,600 & & & \\
\hline 1200 & 8.89 & 5,740 & 0800 & 14.56 & 16,100 & Apr. 19 & & \\
\hline 2400 & 8.92 & 5,780 & 1200 & 14.76 & 16,500 & 1200 & 12.38 & 11,800 \\
\hline & & & $\begin{array}{l}1800 \\
2400\end{array}$ & $\begin{array}{l}14.98 \\
15.14\end{array}$ & $\begin{array}{l}17,000 \\
17,400\end{array}$ & 2400 & 12.11 & 11,100 \\
\hline
\end{tabular}




\section{5-4780 East Fork Des Moines River near Burt, Iowa}

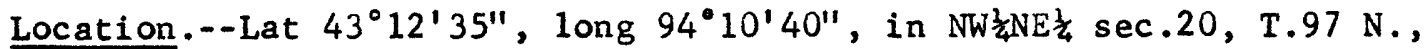
R.28 W., on right bank $30 \mathrm{ft}$ downstream from highway bridge, 0.8 mile upstream from Buffalo Creek, 2.5 miles northeast of Burt, 5.3 miles downstream from Mud Creek, and at mile 389.7 upstream from mouth of Des Moines River.

Drainage area. $--462 \mathrm{sq} \mathrm{mi}$.

Gage-height record.--Digital-recorder tape punched at 15-minute intervals. Datum of gage is $1,114.42 \mathrm{ft}$ above mean sea leve1, datum of 1929. Prior to Sept. 30, 1966, graphic water-stage recorder chart for same site and datum.

Discharge record.--Stage-discharge relation defined by current-meter measurements. Backwater from ice Mar. 1 to Apr. 9, 1965 (no gageheight record Mar. 1-15, 18-30, 1965).

Maxima.--March-May 1965: Discharge, 5,000 cfs Apr. 6 (gage height, $14.21 \mathrm{ft}$ ). ft).

March-May 1969: Discharge, 3,280 cfs Apr. 8 (gage height, 12.09

Period of flood record, $1952-69$ (excluding 1965 and 1969 floods): Discharge 3,870 cfs June 21, 1954 (gage height, $12.67 \mathrm{ft}$ ).

Remarks.--Tables of daily discharge and detailed hydrographs for flood of June 21, 1954, published in U.S. Geological Survey Water-Supply Paper 1370-A.

Mean discharge, in cubic feet per second, 1965

\begin{tabular}{|c|c|c|c|c|c|c|c|c|}
\hline Day & April & May & Day & April & May & Day & April & May \\
\hline $\begin{array}{l}\ldots \\
2 \ldots \\
3 \ldots \\
4 \ldots \\
5 \ldots \\
6 \ldots \\
7 \ldots \\
8 \ldots\end{array}$ & $\begin{array}{r}400 \\
470 \\
660 \\
1,100 \\
2,000 \\
3,900 \\
3,600 \\
3,900\end{array}$ & $\begin{array}{r}1,000 \\
960 \\
888 \\
828 \\
858 \\
1,110 \\
1,180 \\
1,230\end{array}$ & $\begin{array}{l}11 \ldots \\
12 \ldots \\
13 \ldots \\
14 \ldots \\
15 \ldots \\
16 \ldots \\
17 \ldots \\
18 \ldots\end{array}$ & $\begin{array}{l}3,110 \\
2,920 \\
2,680 \\
2,480 \\
2,340 \\
2,190 \\
2,090 \\
1,980\end{array}$ & $\begin{array}{r}1,110 \\
1,020 \\
920 \\
844 \\
814 \\
883 \\
876 \\
837\end{array}$ & $\begin{array}{l}21 \ldots \\
22 \ldots \\
23 \ldots \\
24 \ldots \\
25 \ldots \\
26 \ldots \\
27 \ldots \\
28 \ldots\end{array}$ & $\begin{array}{l}1,550 \\
1,450 \\
1,340 \\
1,270 \\
1,250 \\
1,310 \\
1,260 \\
1,230\end{array}$ & $\begin{array}{l}682 \\
650 \\
625 \\
610 \\
625 \\
744 \\
884 \\
848\end{array}$ \\
\hline $9 \ldots$ & $\begin{array}{l}4,500 \\
3,490\end{array}$ & $\begin{array}{l}1,120 \\
1,040\end{array}$ & $\begin{array}{l}19 \ldots \\
20 \ldots\end{array}$ & $\begin{array}{l}1,820 \\
1,700\end{array}$ & $\begin{array}{l}828 \\
762\end{array}$ & $\begin{array}{l}29 \ldots \\
30 \ldots \\
31 \ldots\end{array}$ & $\begin{array}{c}1,170 \\
1,090 \\
\ldots\end{array}$ & $\begin{array}{l}807 \\
741 \\
688 \\
\end{array}$ \\
\hline \multicolumn{7}{|c|}{ 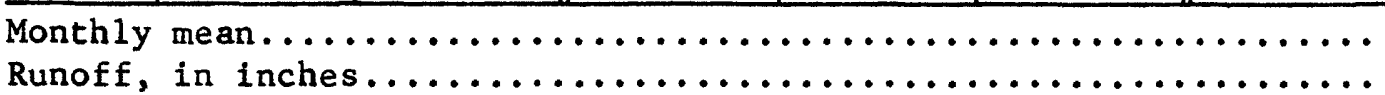 } & $\begin{array}{r}2,008 \\
4.85\end{array}$ & $\begin{array}{r}871 \\
2.17\end{array}$ \\
\hline
\end{tabular}


42

East Fork Des Moines River near Burt, Iowa--Continued

Gage height, in feet, and discharge, in cubic feet per second at indicated time, 1965

\begin{tabular}{|c|c|c|c|c|c|c|c|c|}
\hline Hour & $\begin{array}{c}\text { Gage } \\
\text { height }\end{array}$ & $\begin{array}{c}\text { Dis- } \\
\text { charge }\end{array}$ & Hour & $\begin{array}{c}\text { Gage } \\
\text { height }\end{array}$ & $\begin{array}{l}\text { Dis- } \\
\text { charge }\end{array}$ & Hour & $\begin{array}{c}\text { Gage } \\
\text { height }\end{array}$ & $\begin{array}{l}\text { Dis- } \\
\text { charge }\end{array}$ \\
\hline$\frac{\text { Mar. } 30}{2400}$ & 7.31 & & $\begin{array}{r}\text { Apr. } 4 \\
1600 \\
2400\end{array}$ & $\begin{array}{l}11.98 \\
12.32\end{array}$ & \multirow{23}{*}{5,000} & $\begin{array}{r}\text { Apr. } 9 \\
0800 \\
1500\end{array}$ & $\begin{array}{l}13.46 \\
13.37\end{array}$ & $\begin{array}{l}4,930 \\
4,810\end{array}$ \\
\hline Mar. 31 & & & & & & 2000 & 13.12 & 4,360 \\
\hline 1000 & 7.45 & & Apr. 5 & & & \multirow{11}{*}{$\begin{array}{c}2400 \\
\text { Apr. } 10 \\
1200 \\
2400 \\
\text { Apr. } 11 \\
\begin{array}{c}1200 \\
2400\end{array} \\
\text { Apr. } 12 \\
2400\end{array}$} & \multirow[t]{3}{*}{12.85} & \multirow[t]{2}{*}{3,700} \\
\hline 1400 & 7.65 & & 0300 & 12.65 & & & & \\
\hline 1600 & 8.09 & & 0600 & 12.98 & & & & \multirow{4}{*}{$\begin{array}{l}3,480 \\
3,280\end{array}$} \\
\hline 1800 & 8.89 & & 2400 & 13.53 & & & \multirow{3}{*}{$\begin{array}{l}12.74 \\
12.54\end{array}$} & \\
\hline 2000 & 9.39 & & & & & & & \\
\hline 2400 & 9.83 & & $\frac{\text { Apr. } 6}{1200}$ & 13.90 & & & & \\
\hline Apr. 1 & & & 1600 & 14.14 & & & 12.40 & 3,100 \\
\hline 1200 & 10.33 & & 2100 & 14.21 & & & 12.28 & 2,980 \\
\hline 1600 & 10.47 & & 2400 & 14.19 & & & & \\
\hline 2100 & 10.97 & & & & & & & \\
\hline 2400 & 10.89 & & Apr. 7 & & & & 12.17 & 2,860 \\
\hline Apr. 2 & & & $\begin{array}{l}1200 \\
2400\end{array}$ & $\begin{array}{l}13.74 \\
13.64\end{array}$ & & Apr 13 & & \\
\hline 1200 & 10.69 & & & & & 2400 & 11.95 & 2,500 \\
\hline 2400 & 10.72 & & Apr. 8 & & & & & \\
\hline & & & 0400 & 13.64 & & & & \\
\hline$\frac{\text { Apr. } 3}{1200}$ & & & 1800 & 13.96 & & & & \\
\hline $\begin{array}{l}1200 \\
1500\end{array}$ & 10.76 & & & 13.84 & & & & \\
\hline 1600 & 11.15 & & & & & & & \\
\hline 1700 & 11.35 & & & & & & & \\
\hline 1900 & 11.65 & & & & & & & \\
\hline 2400 & 11.80 & & & & & & & \\
\hline
\end{tabular}


5-4790 East Fork Des Moines River at Dakota City, Iowa

Location.--Lat $42^{\circ} 43^{\prime} 25^{\prime \prime}$, long $94^{\circ} 11^{\prime} 30^{\prime \prime}$, in NW $\frac{1}{4} \operatorname{SE} \frac{1}{4}$ sec.6, T.91 N., R.28 W., on right bank $50 \mathrm{ft}$ upstream from old mill dam, in city park at east edge of Dakota City, $500 \mathrm{ft}$ upstream from county highway bridge, 0.6 mile downstream from bridge on State Highway $3,3.4$ miles upstream from confluence with West Fork Des Moines River and at mile 333.85 upstream from mouth of Des Moines River.

Drainage area.--1,308 sq mi. At site used prior to 0ct. 1, 1954, $1,268 \mathrm{sq} \mathrm{mi}$.

Gage-height record.--Water-stage recorder graph. Datum of gage is $1,038.71 \mathrm{ft}$ above mean sea level, datum of 1929. Prior to Oct. 1, 1954, wire-weight gage at site 8 miles upstream at different datum.

Discharge record.--Stage-discharge relation defined by current-meter measurements. Backwater from ice Mar. 1 to Apr. 6, 1965.

Maxima.--March-May 1965: Discharge, 15,700 cfs Apr. 9 (gage height, $23.13 \mathrm{ft}$ ). ft).

March-May 1969: Discharge, 5,990 cfs Apr. 9 (gage height, 16.21

Period of flood record, 1938, 1940-69 (excluding 1965 and 1969 floods): Discharge $18,800 \mathrm{cfs}$ June 21, 1954 (gage height $16.95 \mathrm{ft}$, from floodmark, site and datum then in use). Flood of June 21, 1954, reached a stage of $24.02 \mathrm{ft}$ (discharge $17,400 \mathrm{cfs}$ ) at present site.

Remarks.--Tables of daily discharges and detailed hydrograph for flood of June 20, 1954, published in U.S. Geological Survey Water-Supply Paper 1370-A.

Mean discharge, in cubic feet per second, 1965

\begin{tabular}{|c|c|c|c|c|c|c|c|c|}
\hline Day & April & May & Day & April & May & Day & April & May \\
\hline $\begin{array}{c}1 \ldots \\
2 \ldots \\
3 \ldots \\
4 \ldots \\
5 \ldots \\
6 \ldots \\
7 \ldots \\
8 \ldots \\
9 \ldots \\
10 \ldots\end{array}$ & $\begin{array}{r}1,020 \\
1,520 \\
3,000 \\
4,700 \\
7,000 \\
10,800 \\
14,400 \\
15,400 \\
15,400 \\
13,200\end{array}$ & $\begin{array}{l}2,420 \\
2,250 \\
2,070 \\
1,910 \\
1,780 \\
1,680 \\
1,570 \\
1,540 \\
1,600 \\
1,710\end{array}$ & $\begin{array}{l}11 \ldots \\
12 \ldots \\
13 \ldots \\
14 \ldots \\
15 \ldots \\
16 \ldots \\
17 \ldots \\
18 \ldots \\
19 \ldots \\
20 \ldots\end{array}$ & $\begin{array}{r}10,600 \\
8,520 \\
7,460 \\
6,660 \\
6,000 \\
5,410 \\
4,930 \\
4,450 \\
4,050 \\
3,700\end{array}$ & $\begin{array}{l}1,770 \\
1,760 \\
1,690 \\
1,650 \\
1,720 \\
1,890 \\
1,960 \\
1,880 \\
1,810 \\
1,780\end{array}$ & $\begin{array}{l}21 \ldots . \\
22 \ldots \\
23 \ldots \\
24 \ldots \\
25 \ldots \\
26 \ldots \\
27 \ldots \\
28 \ldots \\
29 \ldots \\
30 \ldots \\
31 \ldots \\
\end{array}$ & $\begin{array}{c}3,380 \\
3,090 \\
2,850 \\
2,650 \\
2,560 \\
2,570 \\
2,580 \\
2,550 \\
2,560 \\
2,540 \\
\ldots-\end{array}$ & $\begin{array}{l}1,720 \\
1,630 \\
1,550 \\
1,470 \\
1,460 \\
2,120 \\
2,250 \\
1,990 \\
1,900 \\
1,970 \\
1,970\end{array}$ \\
\hline \multicolumn{7}{|c|}{ 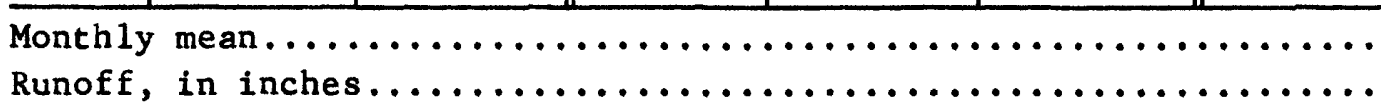 } & $\begin{array}{r}5,852 \\
4.99\end{array}$ & $\begin{array}{r}1,822 \\
1.61\end{array}$ \\
\hline
\end{tabular}


East Fork Des Moines River at Dakota City, Iowa--Continued

Gage height, in feet, and discharge, in cubic feet per second at indicated time, 1965

\begin{tabular}{|c|c|c|c|c|c|c|c|c|}
\hline Hour & $\begin{array}{c}\text { Gage } \\
\text { height }\end{array}$ & $\begin{array}{c}\text { Dis- } \\
\text { charge }\end{array}$ & Hour & $\begin{array}{c}\text { Gage } \\
\text { height }\end{array}$ & $\begin{array}{l}\text { Dis- } \\
\text { charge }\end{array}$ & Hour & $\begin{array}{c}\text { Gage } \\
\text { height }\end{array}$ & $\begin{array}{l}\text { Dis- } \\
\text { charge }\end{array}$ \\
\hline $\begin{array}{r}\frac{\text { Mar. } 30}{2400} \\
\text { Mar. } 31 \\
0600 \\
1200 \\
1400 \\
1700 \\
2400 \\
\text { Apr. } 1 \\
1200 \\
1800 \\
2400 \\
\text { Apr. } 2 \\
0800 \\
2400 \\
\text { Apr. } 3 \\
2400\end{array}$ & $\begin{array}{r}9.00 \\
9.25 \\
9.63 \\
10.26 \\
11.12\end{array}$ & & $\begin{array}{r}\text { Apr. } 4 \\
1200 \\
1700 \\
1900 \\
2400 \\
\text { Apr. } 5 \\
0900 \\
2400 \\
\text { Apr. } 6 \\
0400 \\
0800 \\
1200 \\
2400 \\
\text { Apr. } 7 \\
0400 \\
0800 \\
1200 \\
2400\end{array}$ & $\begin{array}{l}21.50 \\
20.13 \\
20.36 \\
21.85\end{array}$ & $\begin{array}{l}11,200 \\
13,600 \\
14,000 \\
13,500 \\
14,400 \\
15,400\end{array}$ & $\begin{array}{l}\frac{\text { Apr. } 8}{1200} \\
2400 \\
\text { Apr. } 9 \\
0500 \\
1200 \\
2400 \\
\text { Apr. } 10 \\
2400 \\
\text { Apr. } 11 \\
2400 \\
\text { Apr. } 12 \\
0600 \\
1800 \\
2400\end{array}$ & $\begin{array}{l}20.81 \\
19.07\end{array}$ & $\begin{array}{l}15,300 \\
15,600 \\
15,700 \\
15,600 \\
14,500 \\
11,900\end{array}$ \\
\hline
\end{tabular}

Mean discharge, in cubic feet per second, 1969

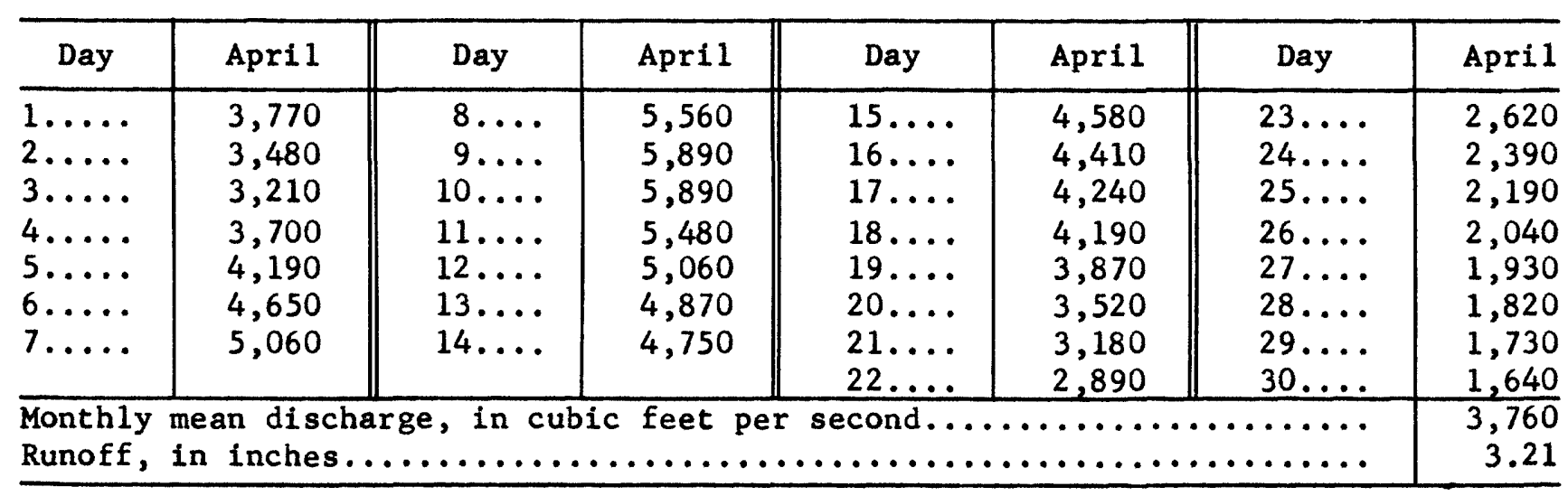




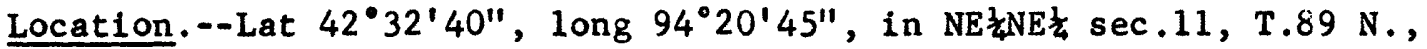
R.30 W., on right bank $20 \mathrm{ft}$ downstream from county highway bridge, 3 miles south of Clare, 8 miles northwest of Fort Dodge, and 8.9 miles upstream from South Lizard Creek.

Drainage area. $--257 \mathrm{sq} \mathrm{mi}$.

Gage-height record.--Digital-recorder tape punched at 15-minute intervals since July 18, 1967. Concrete control since Oct. 11, 1956. Datum of gage 1,079.30 ft above mean sea level, datum of 1929 . Prior to May 6, 1953, wire-weight gage and May 6, 1953, to July 18, 1967, water-stage recorder graph at same site and datum.

Discharge record.--Stage-discharge relation defined by current-meter measurements and by logarithmic plotting above 4,500 cfs.

Maxima.--April 1969: Discharge, 1,490 cfs Apr. 5 (gage height, $6.96 \mathrm{ft}$ ).

Period of flood record, March 1940-69: Discharge, 10,000 cfs June 23, 1947 (gage height, 16.0 ft from floodmark).

Remarks.--Tables of daily discharge and detailed hydrograph for flood of June 20, 1954, (second highest of record) published in U.S. Geological Survey Water-Supply Paper 1370-A. 


\section{5-4805 Des Moines River at Fort Dodge, Iowa}

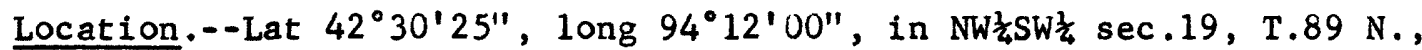
R.28 W., on right bank $400 \mathrm{ft}$ upstream from Soldier Creek, 1,800 ft downstream from Illinois-Central Railroad bridge in Fort Dodge, 2,000 ft downstream from Lizard Creek, and at mile 314.6.

Drainage area. $--4,190 \mathrm{sq} \mathrm{mi}$.

Gage-height record.--Water-stage recorder graph since Dec. 8, 1949. Datum of gage is $969.38 \mathrm{ft}$ above mean sea level, datum of 1929. Apr. 22, 1905, to July 19, 1906, chain gage at bridge, 3,000 ft downstream, at different datum. Oct. 18, 1913, to Oct. 20, 1921, June 20 to Sept. 30, 1927, chain gage, and Oct. 21, 1921, to June 19, 1927, water-stage recorder, at site 7 miles downstream at Kalo, at different datum. Oct. 1, 1946, to Dec. 7, 1949, wire-weight gage at bridge 1,800 ft upstream from present site, at present datum.

Discharge record.--Stage-discharge relation defined by current-meter measurements.

Maxima.--March-May 1965: Discharge, 35,600 cfs Apr. 8, 1965 (gage height, $17.79 \mathrm{ft}$ ).

March-May 1969: Discharge, 22,900 cfs Apr. 15, 1969 (gage height, $12.83 \mathrm{ft}$ ).

Period of flood record, 1905-06, 1914-27, 1947-69 (excluding 1965 and 1969 floods): Discharge, 35,400 cfs June 21, 1954 (gage height, $19.28 \mathrm{ft}$ ).

Remarks.--Tables of daily discharges and detailed hydrograph for flood of June 1954 published in U.S. Geological Survey Water-Supply Paper 1370-A.

Mean discharge, in cubic feet per second, 1965

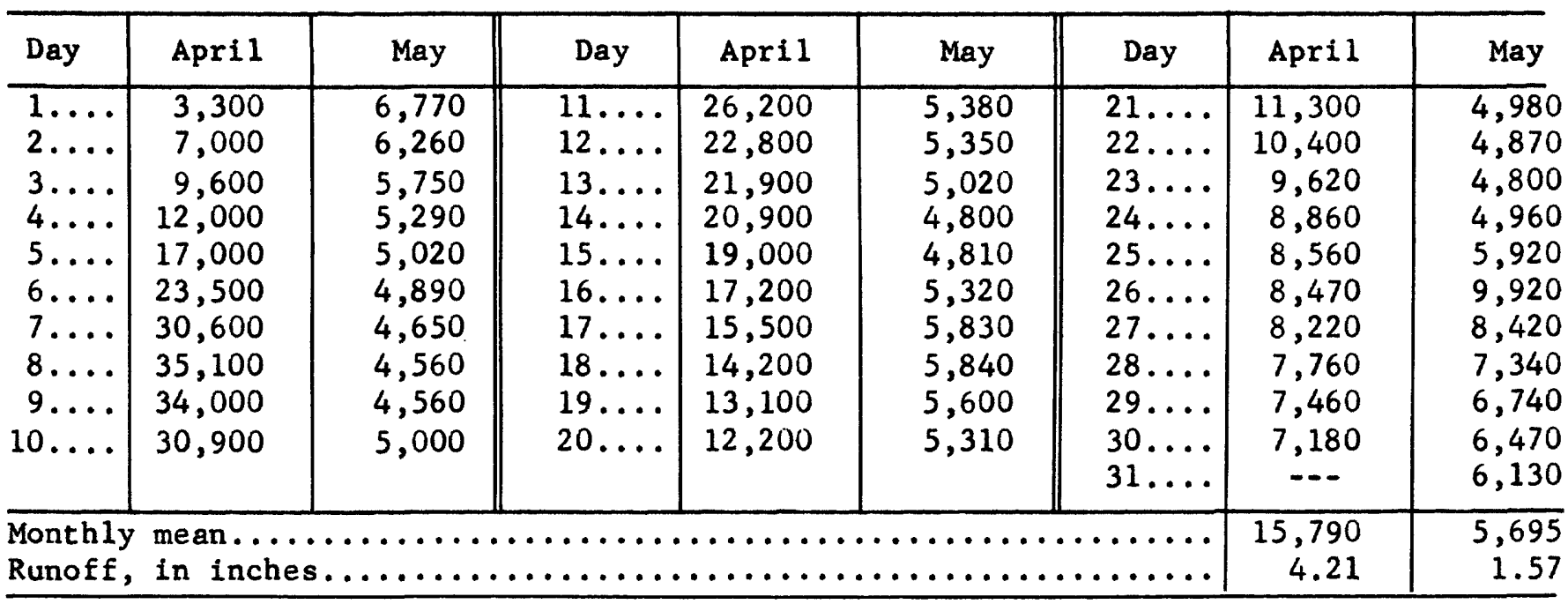


Des Moines'River at Fort Dodge, Iowa--Continued

Gage height, in feet, and discharge in cubic feet per second at indicated time, 1965

\begin{tabular}{|c|c|c|c|c|c|c|c|c|}
\hline Hour & $\begin{array}{c}\text { Gage } \\
\text { height }\end{array}$ & $\begin{array}{l}\text { Dis- } \\
\text { charge }\end{array}$ & Hour & $\begin{array}{c}\text { Gage } \\
\text { height }\end{array}$ & $\begin{array}{l}\text { Dis- } \\
\text { charge }\end{array}$ & Hour & $\begin{array}{c}\text { Gage } \\
\text { height }\end{array}$ & $\begin{array}{l}\text { Dis- } \\
\text { charge }\end{array}$ \\
\hline $\begin{array}{l}\frac{\text { Mar. } 30}{2400} \\
\text { Mar. } 31 \\
\end{array}$ & 4.79 & & $\begin{array}{r}\text { Apr. } 7 \\
1300 \\
1800 \\
2000\end{array}$ & $\begin{array}{l}15.96 \\
16.97 \\
17.16\end{array}$ & $\begin{array}{l}30,300 \\
33,200 \\
33,800\end{array}$ & $\frac{\text { Apr. } 13}{2000}$ & $\begin{array}{l}13.03 \\
12.99\end{array}$ & $\begin{array}{l}22,000 \\
21,900\end{array}$ \\
\hline 0830 & 6.61 & & 2400 & 17.35 & 34,300 & Apr. 14 & & \\
\hline $\begin{array}{l}1200 \\
2400\end{array}$ & $\begin{array}{l}4.28 \\
8.11\end{array}$ & & Apr. 8 & & & $\begin{array}{l}1200 \\
2400\end{array}$ & $\begin{array}{l}12.62 \\
12.26\end{array}$ & $\begin{array}{l}20,900 \\
19,900\end{array}$ \\
\hline Apr. 1 & & & $\begin{array}{l}0400 \\
0600\end{array}$ & $\begin{array}{l}17.55 \\
17.67\end{array}$ & $\begin{array}{l}34,900 \\
35,200\end{array}$ & Apr. 15 & & \\
\hline 1200 & 8.11 & & 0630 & 17.79 & 35,600 & 1200 & 11.94 & 19,000 \\
\hline 2400 & 9.37 & & $\begin{array}{l}1600 \\
1700\end{array}$ & $\begin{array}{l}17.70 \\
17.60\end{array}$ & $\begin{array}{l}35,300 \\
35,000\end{array}$ & 2400 & 11.63 & 18,200 \\
\hline$\frac{\text { Apr. } 2}{1200}$ & 8.41 & & 2400 & 17.58 & 35,000 & $\frac{\text { Apr. } 16}{1800}$ & 11.06 & 16,700 \\
\hline 2400 & 9.36 & & $\frac{\text { Apr. } 9}{1200}$ & 17.29 & 34,100 & 2400 & 10.89 & 16,200 \\
\hline$\frac{\text { Apr. } 3}{0730}$ & 9.17 & & 2400 & 16.90 & 33,000 & $\frac{\text { Apr. } 17}{0800}$ & 10.69 & 15,700 \\
\hline $\begin{array}{l}1200 \\
2400\end{array}$ & $\begin{array}{r}9.46 \\
10.20\end{array}$ & & $\frac{\text { Apr. } 10}{1200}$ & $\begin{array}{l}16.21 \\
15.38\end{array}$ & $\begin{array}{l}31,000 \\
28,600\end{array}$ & $\begin{array}{l}1000 \\
1200 \\
2400\end{array}$ & $\begin{array}{l}10.58 \\
10.59 \\
10.35\end{array}$ & $\begin{array}{l}15,400 \\
15,500 \\
14,900\end{array}$ \\
\hline $\begin{array}{r}\text { Apr. } 4 \\
1200 \\
2400\end{array}$ & $\begin{array}{l}10.68 \\
11.97\end{array}$ & & $\frac{\text { Apr. } 11}{1200}$ & $\begin{array}{l}14.47 \\
13.88\end{array}$ & $\begin{array}{l}26,000 \\
24,300\end{array}$ & $\frac{\text { Apr. } 18}{1200}$ & $\begin{array}{r}10.08 \\
9.85\end{array}$ & $\begin{array}{l}14,200 \\
13,600\end{array}$ \\
\hline$\frac{\text { Apr. } 5}{1200}$ & 12.53 & & Apr. 12 & & & Apr. 19 & & \\
\hline $\begin{array}{l}1700 \\
2400\end{array}$ & $\begin{array}{l}14.98 \\
12.52\end{array}$ & & $\begin{array}{l}1200 \\
1800 \\
2400\end{array}$ & $\begin{array}{l}13.27 \\
13.09 \\
12.98\end{array}$ & $\begin{array}{l}22,600 \\
22,100 \\
21,800\end{array}$ & $\begin{array}{l}0800 \\
1200 \\
2400\end{array}$ & $\begin{array}{l}9.71 \\
9.65 \\
9.46\end{array}$ & $\begin{array}{l}13,300 \\
13,100 \\
12,700\end{array}$ \\
\hline $\begin{array}{r}\text { Apr. } 6 \\
0600 \\
1000 \\
2400\end{array}$ & $\begin{array}{l}12.82 \\
13.38 \\
14.83\end{array}$ & $\begin{array}{l}21,400 \\
22,900 \\
27,000\end{array}$ & & & & & & \\
\hline
\end{tabular}

Mean discharge, in cubic feet per second, 1969

\begin{tabular}{|c|c|c|c|c|c|c|c|}
\hline Day & April & Day & April & Day & April & Day & April \\
\hline $\begin{array}{l}1 \ldots \ldots \\
2 \ldots \ldots \\
3 \ldots \ldots \\
4 \ldots \\
5 \ldots \ldots \\
6 \ldots \ldots\end{array}$ & $\begin{array}{r}7,930 \\
7,600 \\
7,750 \\
11,400 \\
12,300 \\
12,500\end{array}$ & $\begin{array}{r}8 \ldots \\
9 \ldots \\
10 \ldots \\
11 \ldots \\
12 \ldots \\
13 \ldots\end{array}$ & $\begin{array}{l}13,000 \\
13,400 \\
13,700 \\
14,200 \\
16,900 \\
20,700\end{array}$ & $\begin{array}{l}15 \ldots \\
16 \ldots \\
17 \ldots \\
18 \ldots \\
19 \ldots \\
20 \ldots\end{array}$ & $\begin{array}{l}22,600 \\
21,700 \\
20,400 \\
19,400 \\
17,500 \\
15,800\end{array}$ & $\begin{array}{l}23 \ldots \ldots \\
24 \ldots \\
25 \ldots \\
26 \ldots \\
27 \ldots \\
28 \ldots\end{array}$ & $\begin{array}{r}11,500 \\
10,400 \\
9,580 \\
8,860 \\
8,280 \\
7,620\end{array}$ \\
\hline $7 \ldots$. & 12,700 & $14 \ldots$ & 22,600 & $\begin{array}{l}21 \ldots \\
22 \ldots\end{array}$ & $\begin{array}{l}14,200 \\
12,800 \\
\end{array}$ & $\begin{array}{l}29 \ldots \\
30 \ldots \\
\end{array}$ & $\begin{array}{l}7,130 \\
6,750 \\
\end{array}$ \\
\hline
\end{tabular}




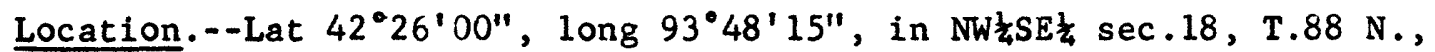
R.25 W., on right bank $10 \mathrm{ft}$ upstream from bridge on State Highway 17, 2 miles south of Webster City, and 4.5 miles downstream from White Fox Creek.

Drainage area. $--844 \mathrm{sq} \mathrm{mi}$.

Gage-height record.--Digital-recorder tape punched at 15-minute intervals. Datum of gage is $989.57 \mathrm{ft}$ above mean sea level, datum of 1929.

Discharge record.--Stage-discharge relation defined by current-meter measurements .

Maxima.--April 1969: Discharge, 3,460 cfs Apr. 6 (gage height, $7.30 \mathrm{ft}$ ).

Period of flood record 1940-April 1969: Discharge, 20,300 cfs June 22, 1954 (gage height, $18.55 \mathrm{ft}$ ).

Maximum stage known since 1896, $19.1 \mathrm{ft}$ about June 10, 1918, from floodmarks, from information by local resident (discharge, 21,500 cfs).

Remarks.--Tables of daily discharges and detailed hydrograph for flood of June 1954 in U.S. Geological Survey Water-Supply Paper 1370-A. 


\section{5-4815 Des Moines River near Boone, Iowa}

Location.--Lat $42^{\circ} 04^{\prime} 38^{\prime \prime}$, long $93^{\circ} 56^{\prime} 06^{\prime \prime}$, in NE $\frac{1}{4} \mathrm{NE} \frac{1}{4}$ sec.24, T.84 N., R.27 W., on left bank $30 \mathrm{ft}$ upstream from Boone Water Department dam, 2 miles northwest of Boone, 2.2 miles upstream from Bluff Creek, and at mile 258.8.

Drainage area. - -5,511 $\mathrm{sq} \mathrm{mi}$.

Gage-height record.--Water-stage recorder graph since Feb. 7, 1935. Concrete control since Oct. 20, 1932. Datum of gage is $872.16 \mathrm{ft}$ above mean sea level, adjustment of 1929 (levels by Corps of Engineers). Chain gage at site 2.5 miles downstream at datum $7.87 \mathrm{ft}$ lower in 1918 .

Discharge record.--Stage-discharge relation defined by current-meter measurements.

Maxima.--March-May 1969: Discharge, 24,000 cfs April 16 (gage height, $14.43 \mathrm{ft}$ ).

Period of flood record 1903, 1905-29, 1931-69: Discharge, 57,400 cfs June 22, 1954 (gage height, $25.35 \mathrm{ft}$, from graph based on hourly gage readings).

Remarks.--Tables of daily discharges and detailed hydrograph for flood of June 1954 published in U.S. Geological Survey Water-Supply Paper 1370-A. 